\title{
The Mechanism and Predictability of an Elevated Convection Initiation Event in a Weak-Lifting Environment in Central-Eastern China
}

\author{
Murong ZHANG AND ZHIYONG MENG \\ Laboratory for Climate and Ocean-Atmosphere Studies, Department of Atmospheric and Oceanic Sciences, \\ School of Physics, Peking University, Beijing, China \\ YIPENG HUANG \\ Laboratory of Straits Meteorology, Xiamen Meteorological Bureau, Xiamen, China
}

DONGYONG WANG

Anhui Meteorological Bureau, Hefei, China

(Manuscript received 21 November 2018, in final form 23 February 2019)

\begin{abstract}
An elevated convection initiation (CI) of a quasi-linear mesoscale convective system (MCS) that occurred in a weak-lifting environment in the early morning on 23 June 2016 in central-eastern China was investigated using observational analysis and convection-permitting numerical simulations. This MCS gradually developed into a surface-based MCS and eventually produced a strong supercell that spawned an EF4 tornado in Yancheng City of Jiangsu Province and killed 98 people. This elevated MCS was initiated ahead of a surface front without identifiable boundaries at the surface. An elevated moist absolutely unstable layer (MAUL) was found to be conducive to the CI. The MAUL provided negligible convective inhibition and contributed to CI without strong-lifting mechanisms. Numerical simulation results showed that the formation of the elevated MAUL was mainly attributed to adiabatic cooling by weak vertical ascent and sufficient horizontal moisture transport near the terminus of a low-level jet. The weak vertical ascent before the CI was sloping and was likely to be relevant to the layer-lifting process associated with the realization of potential instability. The results showed that the MAUL in this weak-lifting environment was characterized by a shallower depth, a weaker lapse rate, and a longer sustaining period than the conditions in a strong-lifting environment. The predictability of this elevated CI case was examined using a 10-member ensemble forecast. A total of $80 \%$ of the ensemble members captured the CI. Rather than a difference in lifting, whether having an elevated MAUL or not was the major difference between CI and non-CI members in the present case.
\end{abstract}

\section{Introduction}

Nocturnal mesoscale convective systems (MCSs) frequently occur in many places in the world such as the central United States (e.g., Maddox 1980; Carbone et al. 2002; Parker 2008) and central-eastern China (e.g., Zheng et al. 2013). These systems produce a considerable portion of the warm-season precipitation (e.g., Wallace 1975; Bentley and Mote 1998; Yu et al. 2007; Chen et al. 2010) and pose a great threat to public safety and property, with hailstorms, flooding, and even tornadoes occurring (e.g., Wilson et al. 2018; Trier et al. 2006; Kis and Straka 2010). Nocturnal MCSs are often

Corresponding author: Dr. Zhiyong Meng, zymeng@pku.edu.cn associated with elevated convection initiation (CI) (e.g., Colman 1990; Weckwerth et al. 2004; Geerts et al. 2017; Reif and Bluestein 2017), where the source of the convective updraft originates above the stable nocturnal planetary boundary layer (PBL). Unlike surface-based CI, elevated CI often occurs without identifiable surface boundaries (e.g., gust fronts and drylines) as precursors (Wilson and Roberts 2006), presenting a great challenge in the forecasting of CI and subsequent MCSs (Davis et al. 2003).

Elevated CI mechanisms have been widely discussed in previous studies. Wilson and Roberts (2006) showed that midlevel convergence and conditional instability were important in initiating nocturnal storms during IHOP_2002 (Weckwerth et al. 2004). Other studies 
revealed that gravity waves and bores in stable environments are also favorable lifting mechanisms for elevated CI (e.g., Marsham et al. 2011; Wilson et al. 2018). Elevated CI, which produces a considerable portion of nocturnal CI (Reif and Bluestein 2017), can occur in an environment with weak but persistent mesoscale ascent without obvious small-scale lifting mechanisms (Trier et al. 2017).

Elevated CI in a weak-lifting environment is sometimes characterized by low-level moist absolute unstable layers (MAULs; Bryan and Fritsch 2000), which are saturated layers with lapse rates greater than moist adiabatic rates (i.e., equivalent potential temperature $\theta_{e}$ decreasing with height). A MAUL can support elevated $\mathrm{CI}$ in the absence of strong vertical motion since all parcels in the MAUL have negligible convective inhibition (CIN) and are unstable in response to slight vertical displacement. Based on observations from the Plains Elevated Convection at Night (PECAN) 2015 field campaign (Geerts et al. 2017), recent studies have qualitatively shown that the formation of a MAUL associated with elevated CI may be attributed to a nocturnal low-level jet (LLJ; Gebauer et al. 2018; Shapiro et al. 2018), weak but persistent vertical motion (Trier et al. 2017), and warm advection (e.g., Reif and Bluestein 2017; Wilson et al. 2018). However, the thermodynamic field evolutions associated with the development of elevated MAULs before CI and their quantitative contributions to the formation of MAULs have been less studied. In addition, although the characteristics of MAULs in a stronglifting environment have been studied in deep convection, such as those in typhoon eyewalls (Barnes 2008) and squall lines (Bryan 2005), the temporal and spatial scales of a MAUL in a weak-lifting environment have rarely been addressed in the literature.

The predictability of elevated $\mathrm{CI}$ in a weak-lifting environment is also an important issue considering the rather limited prediction capability of state-of-the-art convectionpermitting numerical models (Stelten and Gallus 2017). By assimilating in situ and radar observations for a nocturnal CI event, Degelia et al. (2018) noted that nocturnal CI forecast accuracy is closely related to the mesoscale preconvective environment. The elevated MAUL in the preconvective environment has been observed as a common feature that promotes elevated CI in the absence of strong-lifting mechanisms (e.g., Trier et al. 2017). However, whether the elevated MAUL can ensure CI in a weak-lifting environment remains unknown. The CI predictability and its relationship with the MAUL in this scenario need to be further investigated.

The present work investigates the elevated CI of a linear MCS in central-eastern China, where there is the highest recorded rate of squall-line incidents in the whole country (Meng et al. 2013; Huang et al. 2017; (a) Max reflectivity at 0000 UTC 23 June

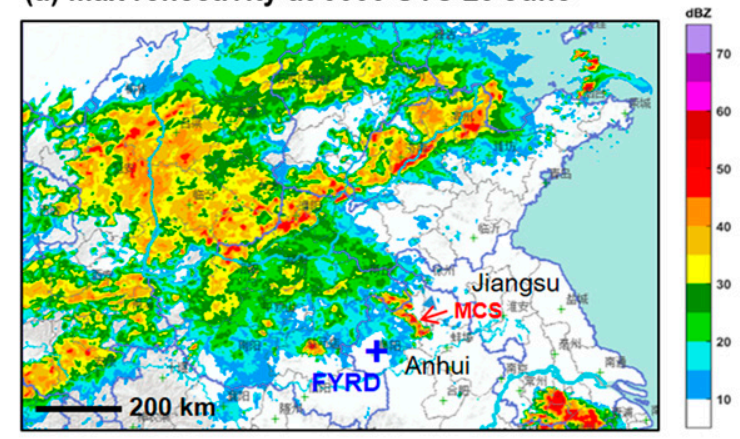

(b) Synoptic environment at 0000 UTC 23 June

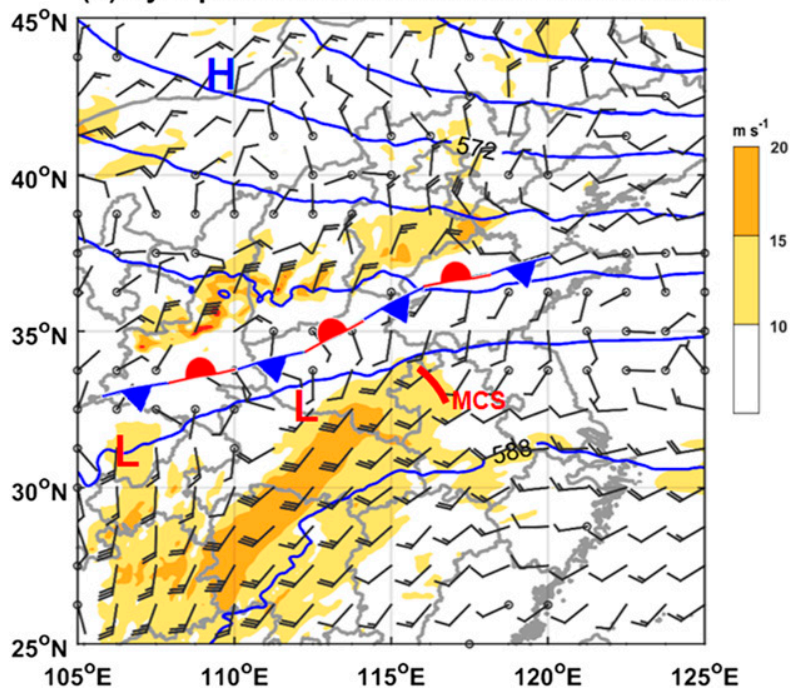

FIG. 1. (a) Mosaics of composite radar reflectivity $(\mathrm{dBZ})$ at 0000 UTC 23 Jun in central-eastern China; the location of the Fuyang radar is marked with a blue cross; the target MCS and the provinces discussed in the text are shown on the map; the distance length scale is given at the bottom left. (b) Synoptic environment reflected by ECMWF HRES analysis at 0000 UTC 23 Jun including 500-hPa geopotential height (contoured in blue every $40 \mathrm{gpm}$ ) and $850-\mathrm{hPa}$ horizontal wind speed (shaded), $850-\mathrm{hPa}$ wind vector $\left(\right.$ barb $=5 \mathrm{~m} \mathrm{~s}^{-1}$, half barb $\left.=2.5 \mathrm{~m} \mathrm{~s}^{-1}\right)$, locations of the surface front and surface high and low pressure (denoted by the front symbols, "H" and "L"); the red line indicates the location of the linear convective system at 0000 UTC 23 Jun.

He et al. 2017). The MCS was initiated at $\sim 0530$ LST $(\mathrm{LST}=\mathrm{UTC}+8 \mathrm{~h}) 23$ June 2016 above a nocturnal stable boundary layer in a weak-lifting environment near the terminus of an LLJ far from the surface front. This linear MCS gradually developed into a surface-based MCS in the daytime and eventually generated an EF4 tornado that killed 98 people, which was the deadliest tornado in the past 41 years in China (Meng et al. 2018). In the current study, analyses were performed based on both observations and convection-permitting simulations to understand the CI, the key factors for the development of an elevated MAUL, and the characteristics of the 


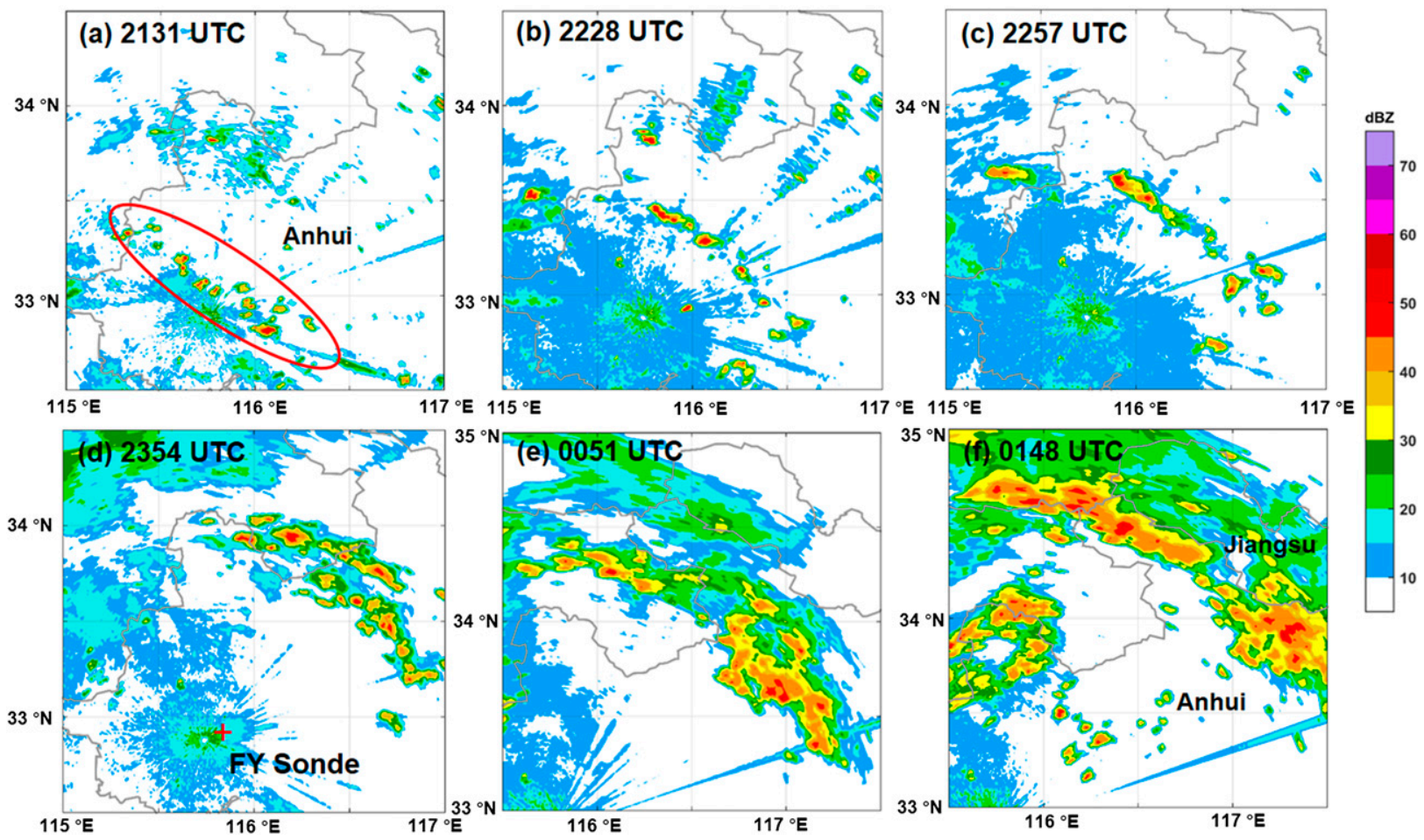

FIG. 2. Composite reflectivity (shaded in dBZ) of the Fuyang radar at (a) 2131 UTC, (b) 2228 UTC, (c) 2257 UTC, and (d) 2354 UTC 22 Jun and (e) 0051 UTC and (f) 0148 UTC 23 Jun. The location of the Fuyang radiosonde is given in (d). Initial convective cells discussed in the text are circled in red in (a). Anhui and Jiangsu provinces (discussed in the text) are marked in (a) and (f). The time of local sunrise was 2109 UTC (0509 LST).

MAUL in this weak-lifting environment. The CI predictability in this scenario and its relationship with the MAUL were also addressed. Section 2 introduces data and methods used in this study. An overview of the CI environment and the evolution of the elevated linear MCS are described in section 3. Section 4 presents the model configurations, the simulated $\mathrm{CI}$, and the formation mechanisms and characteristics of the MAUL in the weak-lifting environment. The CI predictability in this case and its relationship with the MAUL are also examined using ensemble forecasting. The conclusions of this study are given in section 5 .

\section{Data and methods}

The data used in this work included radar data, satellite images, high-resolution analysis (HRES) from European Centre for Medium-Range Weather Forecasts (ECMWF), surface observations, and conventional radiosonde observations. Mosaics of composite radar reflectivity were operationally created every 6 min during this event by the China Meteorological Administration (CMA) based on a network of Chinese next-generation weather radars. The Fuyang S-band Doppler radar, which is similar to the Weather Surveillance Radar-1988
Doppler (WSR-88D) (Zhu and Zhu 2004), is located in Anhui Province (locations of the radar and province are denoted in Fig. 1a). Composite true-color images from the Advanced Himawari Imager (AHI) on board Himawari-8, the new-generation geostationary satellite operated by the Meteorological Satellite Center of the Japan Meteorological Agency, were available every $10 \mathrm{~min}$ with a resolution of $1 \mathrm{~km}$ at nadir. The HRES analysis from ECMWF (detailed information is available online at https://www.ecmwf.int/en/ forecasts/datasets/set-i) is gridded at $0.125^{\circ} \times 0.125^{\circ}$ with a 6-h time interval and was used for synoptic analysis and initial and lateral boundary conditions for numerical simulations. The 10-min surface observations of automatic weather stations in Anhui Province from Anhui Meteorological Bureau and the rawinsonde observation at Fuyang (location denoted in Fig. 2d) from CMA were also used to analyze the CI environment.

\section{Case overview and observational analysis}

A linear MCS occurred in Anhui Province in centraleastern China in the early morning on 23 June 2016 under the influence of an LLJ ahead of a surface front (Fig. 1). At 0000 UTC 23 June 2016, this southeastnorthwest-oriented linear MCS was located in the 

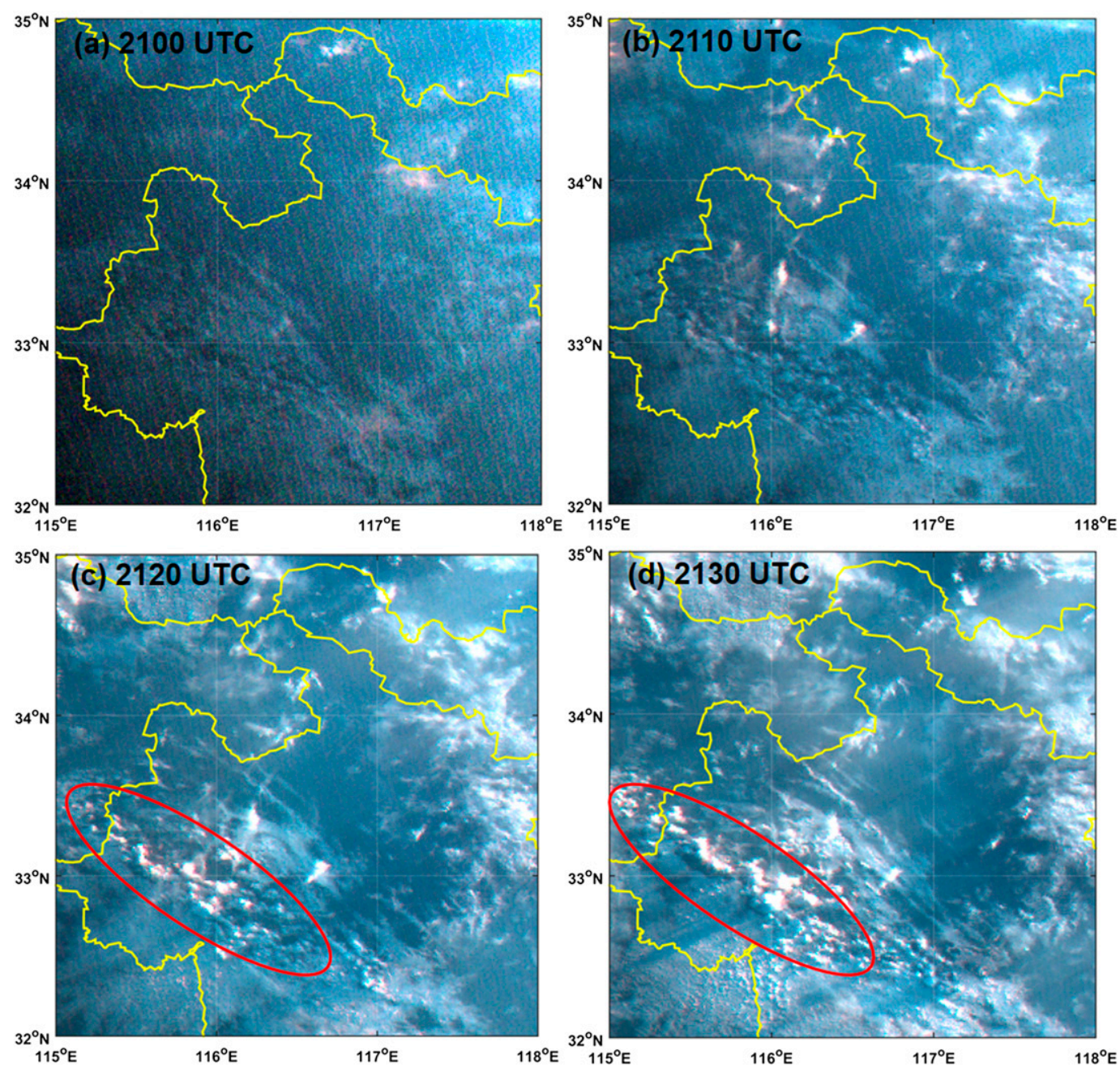

FIG. 3. Composite true-color images from Himawari-8 at (a) 2100 UTC, (b) 2110 UTC, (c) 2120 UTC, and (d) 2130 UTC 22 Jun. The linear-organized cumulus cloud cells are circled in red in (c) and (d).

warm sector approximately $250 \mathrm{~km}$ to the south of the northeast-southwest-oriented surface front (Fig. 1). The synoptic-scale surface front was associated with a $\sim 1000$-km-long quasi-linear rainband to the northwest of the target MCS (Fig. 1a). The MCS occurred near the terminus of an 850 -hPa strong southwesterly jet ${ }^{1}$ without an obvious trough at $500 \mathrm{hPa}$ (Fig. 1b).

Observations of the Fuyang radar revealed the detailed initiation of the linear MCS. Several convective cells were initiated (Fig. 2a) in the early morning at 2131 UTC 22 June (0531 LST) in the northwest of Anhui Province. These cells then gradually merged into an organized linear MCS and intensified as they moved northeastward in the subsequent three hours (Figs. 2b-e). At

\footnotetext{
${ }^{1} 10 \mathrm{~m} \mathrm{~s}^{-1}$ is taken as the threshold for jet region in the present study following Whiteman et al. (1997) and Du et al. (2014).
}

0148 UTC 23 June (Fig. 2f), the linear MCS moved into Jiangsu Province, gradually developed into a surface-based MCS and eventually spawned a strong supercell at 0600 UTC 23 June at its southern end, which led to a severe tornado (EF4) in Jiangsu Province (Meng et al. 2018, in their Fig. 3 and Fig. 8).

The composite true-color satellite images from Himawari-8 also successfully captured the CI. Unlike common daytime CI in which cumulonimbus clouds often explosively develop from shallow cumulus or less cloudy conditions, the sky was overcast with stratiform clouds at 2100 UTC 22 June (Fig. 3a) before the CI, which was likely a result of saturation due to layer lifting. At 2110 UTC 22 June, cumuliform protuberances embedded in the stratiform cloud appeared in a similar manner as the appearance of castellanus (Fig. 3b), which was possibly associated with elevated convection (Corfidi et al. 2008). These protuberances 

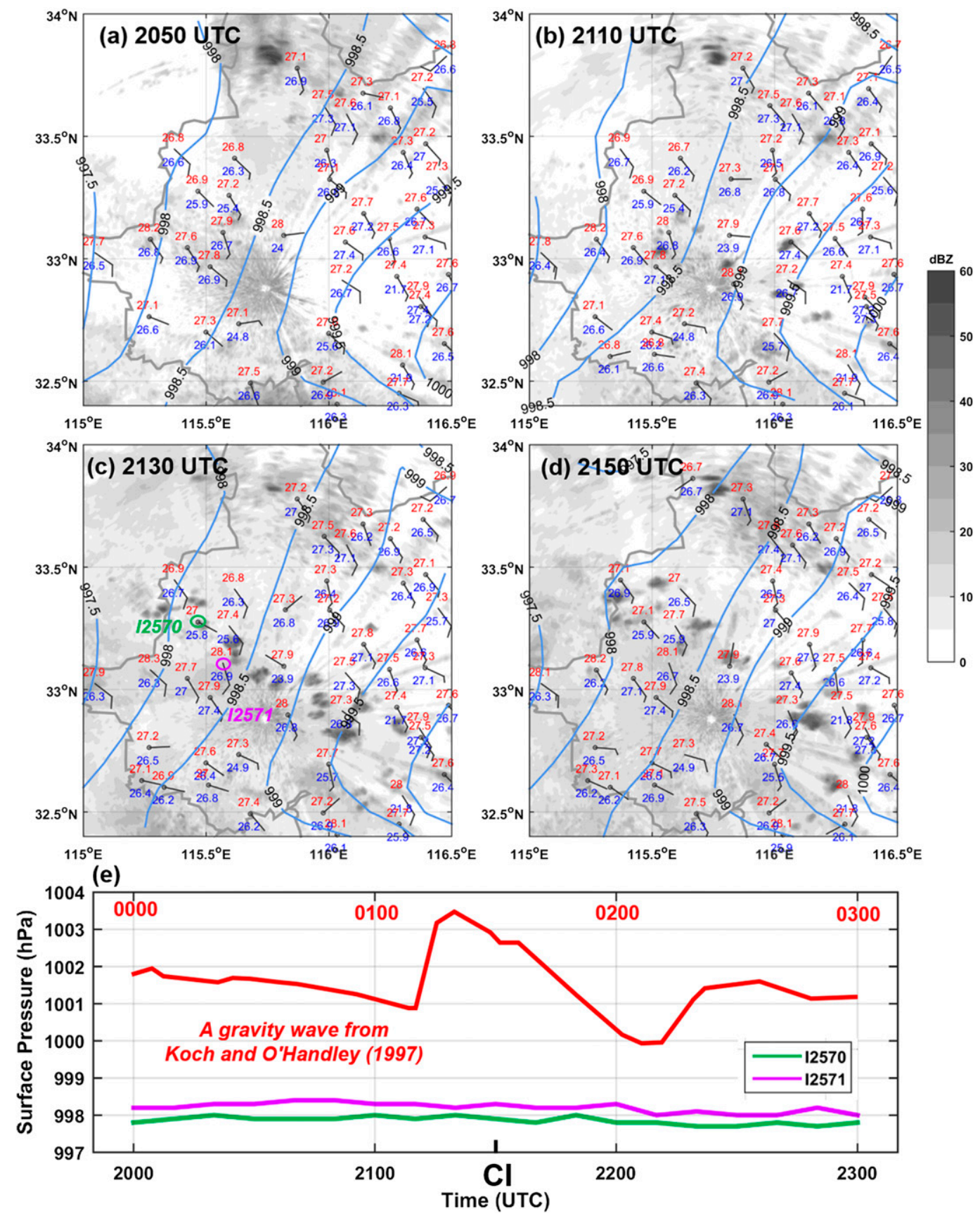

FIG. 4. Surface pressure (contoured in blue every $0.5 \mathrm{hPa}$ ), surface wind vector (barb $=2 \mathrm{~m} \mathrm{~s}^{-1}$, half barb $=$ $1 \mathrm{~m} \mathrm{~s}^{-1}$ ), surface temperature (text in red), and surface dewpoint temperature (text in blue) at (a) 2050 UTC, (b) 2110 UTC, (c) 2130 UTC, and (d) 2150 UTC 22 Jun. The shading denotes the composite reflectivity from the Fuyang radar (dBZ). Time series of surface pressure at station I2570 (green) and I2571 (purple) with locations given in (c) are shown in (e) with CI timing marked on the lower time axis. The pressure trace of a gravity wave from Koch and O'Handley (1997) adapted from their Fig. 18e is also shown in (e) in red with corresponding time (UTC) shown on the upper time axis for reference.

gradually developed into cumulus cloud cells organized in a northwest-southeast-oriented line (Fig. 3c) and eventually generated deep convection at 2130 UTC 22 June (Fig. 3d and Fig. 2a).
Both the surface observations and sounding profiles near the CI location suggested that the initiation of the linear MCS was likely elevated. In the warm sector to the south of the surface front, the near-surface 

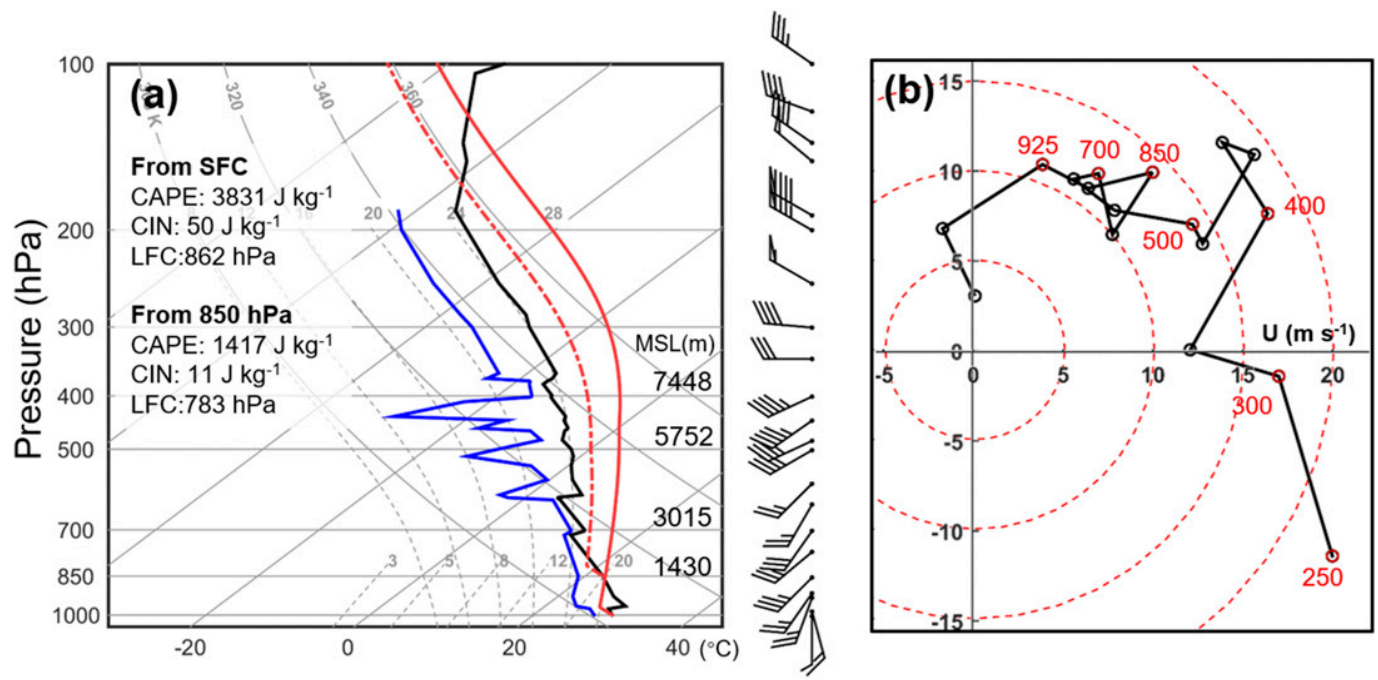

FIG. 5. (a) Skew $T-\log p$ and (b) hodograph diagrams of the Fuyang radiosonde (the red cross in Fig. 2d) at 0000 UTC 23 Jun 2016. In (a), the ambient temperature and dewpoint are represented by the solid black and blue lines, respectively; parcels that ascend undiluted from the surface and $850 \mathrm{hPa}$ are shown by the solid and dashed red lines, respectively; the wind profile is shown on the right side (barb $=4 \mathrm{~m} \mathrm{~s}^{-1}$, half barb $=2 \mathrm{~m} \mathrm{~s}^{-1}$, flag $=$ $20 \mathrm{~m} \mathrm{~s}^{-1}$ ). (b) The velocities at certain pressure levels (hPa) are marked in red circles in the hodograph. CAPE, $\mathrm{CIN}$, and LFC of parcels lifted from different levels are given on the left in (a).

environment was characterized by weak southeasterly wind $\left(\sim 2 \mathrm{~m} \mathrm{~s}^{-1}\right)$ and relatively uniform temperature and humidity fields (Figs. 4a-d), which indicated the absence of identifiable surface boundaries. Observational evidences of gravity wave aiding $\mathrm{CI}$ in the current case were lacking. No obvious wave-like surface pressure patterns (Figs. 4a-d) were found near CI locations. The surface pressure oscillations at stations near CI were also very weak (Fig. 4e) compared with typical mesoscale gravity waves (e.g., Koch and O'Handley 1997, the red curve in Fig. 4e). No alternating bands of radial velocity from Fuyang radar were found either at all elevation angles during 2100-2200 UTC 22 June (figures not shown). The Fuyang radiosonde (location denoted in Fig. 2d) released at 0000 UTC 23 June (Fig. 5) could represent the $\mathrm{CI}$ environment even though the CI occurred $150 \mathrm{~min}$ previously since the radiosonde was located upstream of the convective line and was not contaminated by convection. There was a temperature inversion near the surface that was likely due to the radiative cooling at night (Fig. 5a). This inversion resulted in a surface-based CIN of $50 \mathrm{~J} \mathrm{~kg}^{-1}$, and the parcel had to be lifted by $1284 \mathrm{~m}$ to reach its LFC. However, the elevated moist layer located between 850 and $600 \mathrm{hPa}$ reduced the CIN for parcels lifted above the stable boundary layer. A parcel lifted from $850 \mathrm{hPa}$ had a CIN of $11 \mathrm{~J} \mathrm{~kg}^{-1}$ and a CAPE of $1417 \mathrm{~J} \mathrm{~kg}^{-1}$, which represented a favorable environment for elevated CI (Fig. 5a). The hodograph (Fig. 5b) revealed the LLJ at $850 \mathrm{hPa}$ and the strong vertical wind shear below $3 \mathrm{~km}$ with the $0-3 \mathrm{~km}$ AGL layer bulk wind difference of $9.69 \mathrm{~m} \mathrm{~s}^{-1}$, which were beneficial for the development of an MCS.

\section{Numerical simulation results}

\section{a. Model configurations}

To understand the $\mathrm{CI}$ and its environmental conditions, a 24-h convection-permitting numerical simulation was conducted from 1200 UTC 22 June to 1200 UTC 23 June

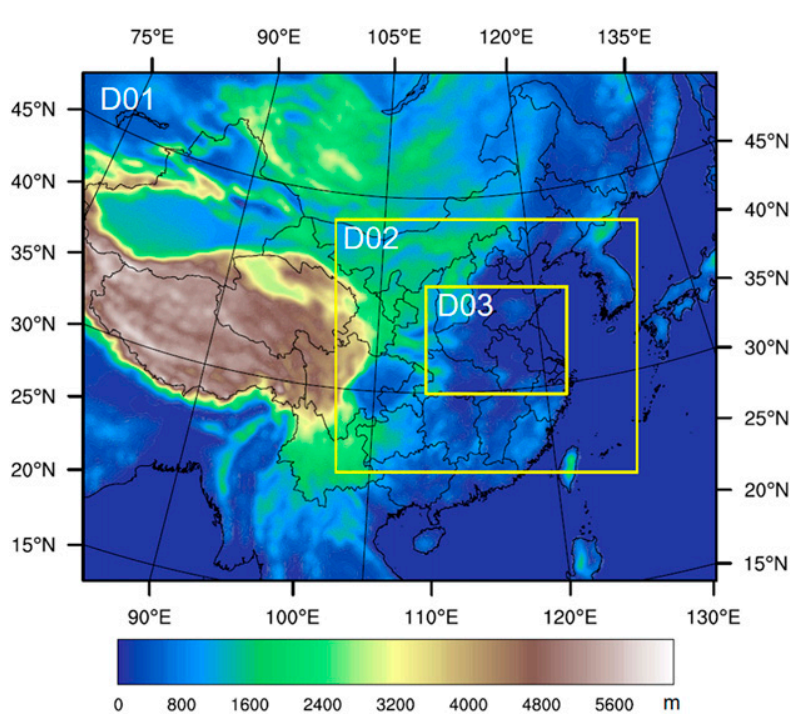

FIG. 6. Terrain height (shaded; unit: $\mathrm{m}$ ) and domains used for the control simulation as well as ensemble forecasts. 

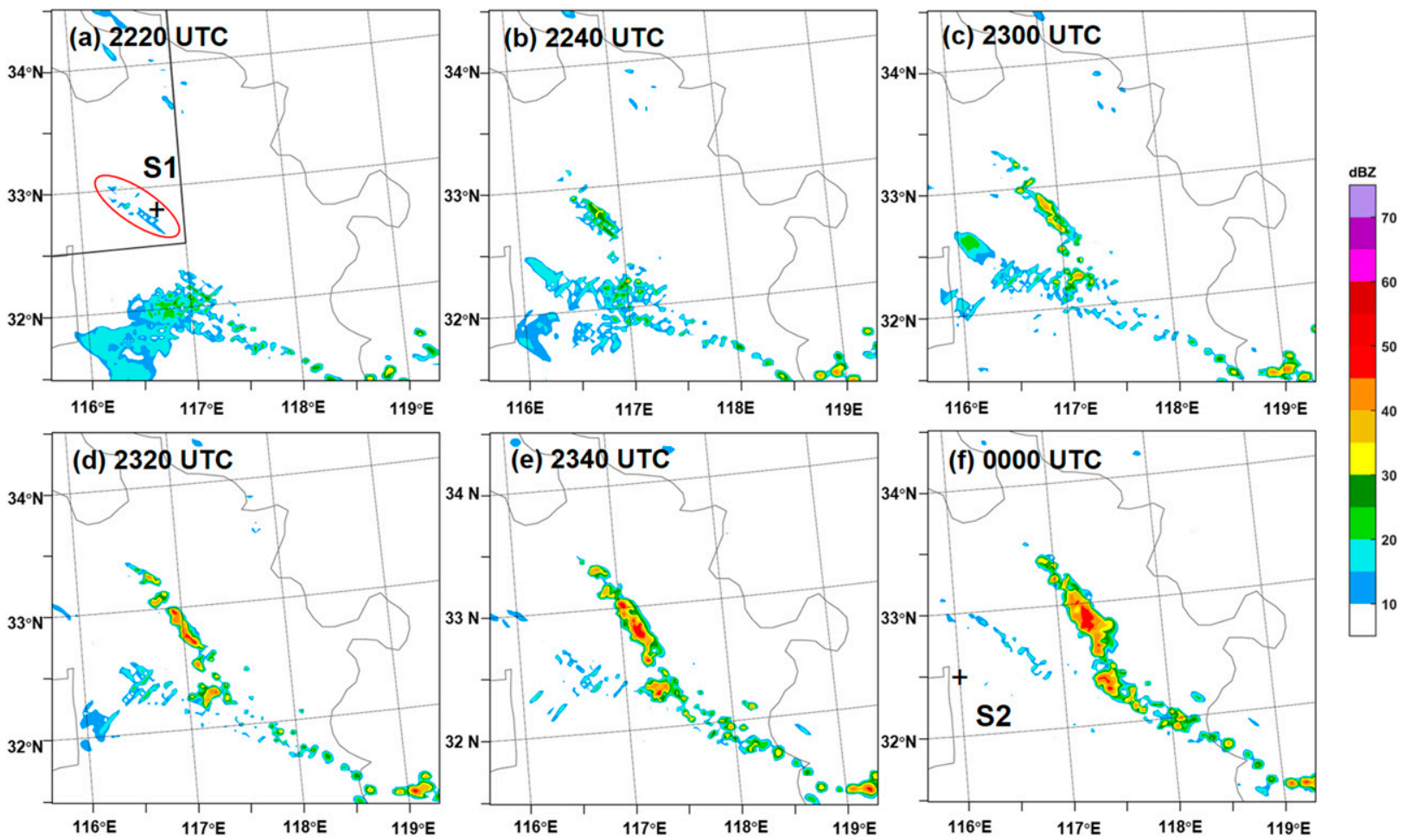

FIG. 7. Model-derived composite radar reflectivity (shaded in $\mathrm{dBZ}$ ) in domain 3 (horizontal resolution of $3 \mathrm{~km}$ ) of the control simulation at (a) 2220 UTC, (b) 2240 UTC, (c) 2300 UTC, (d) 2320 UTC, and (e) 2340 UTC 22 Jun and (f) 0000 UTC 23 Jun. The simulated results hereafter are all from domain 3 (horizontal resolution of $3 \mathrm{~km}$ ). The weak echo discussed in the text is circled in red in (a). Black crosses in (a) and (f) indicate locations of sounding profiles analyzed in Fig. 8. The area of radar observation in Fig. 2a is given as the gray box in (a).

2016 using version 3.7.1 of the WRF-ARW Model (Skamarock et al. 2008). Initial and lateral boundary conditions were obtained from HRES analysis (gridded at $0.125^{\circ} \times 0.125^{\circ}$ ), and the lateral boundary conditions were updated every $6 \mathrm{~h}$. Three two-way nested domains (Fig. 6) with 27-, 9-, and 3-km horizontal grid spacing and 41 vertical levels were used. The single-moment 6-class microphysics scheme (WSM6; Hong and Lim 2006), the (a) S1 at 2220 UTC

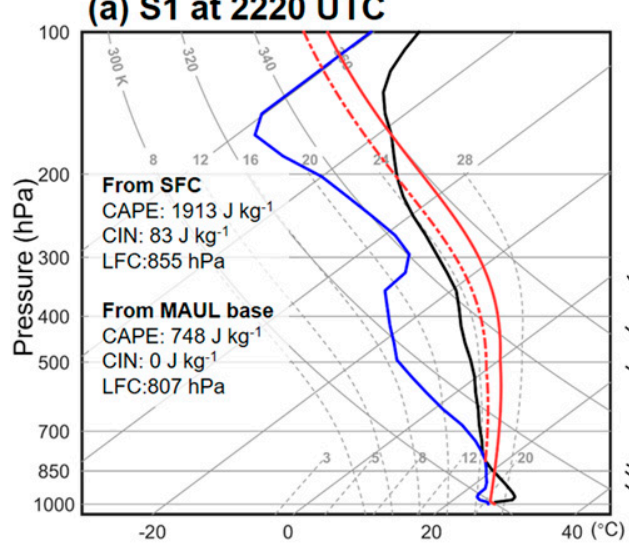

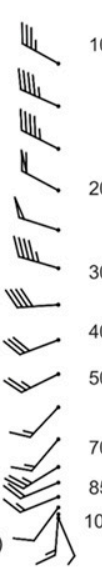

\section{(b) S2 at 0000 UTC}

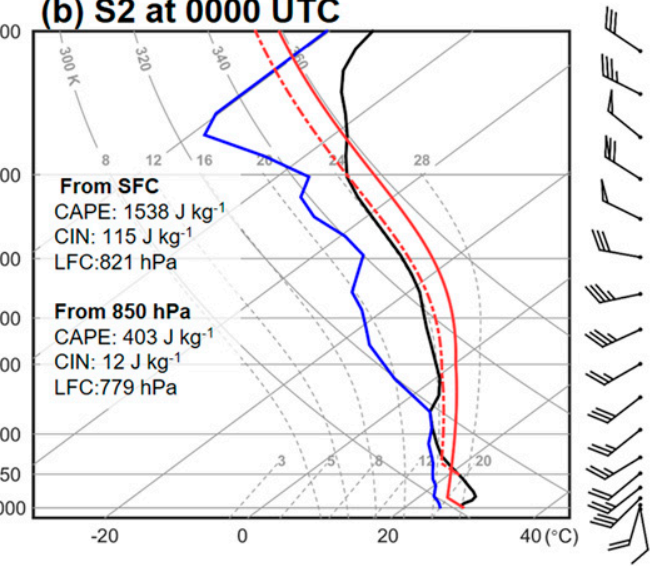

FIG. 8. Skew $T-\log p$ diagrams of sounding derived from the control simulation at (a) 2220 UTC 22 Jun at S1 (black cross in Fig. 7a) and (b) 0000 UTC 23 Jun at S2 (black cross in Fig. 7f). The ambient temperature and dewpoint are represented by the solid black and blue lines, respectively. In (a) S1, parcels that ascend undiluted from the surface and the base of MAUL are shown by the solid and dashed red lines, respectively; In (b) S2, parcels that ascend undiluted from the surface and $850 \mathrm{hPa}$ are shown by the solid and dashed red lines, respectively. The wind profile is shown on the right side (barb $=4 \mathrm{~m} \mathrm{~s}^{-1}$, half barb $=2 \mathrm{~m} \mathrm{~s}^{-1}$, flag $=20 \mathrm{~m} \mathrm{~s}^{-1}$ ). CAPE, CIN, and LFC of parcels lifted from different levels are given on the left. 

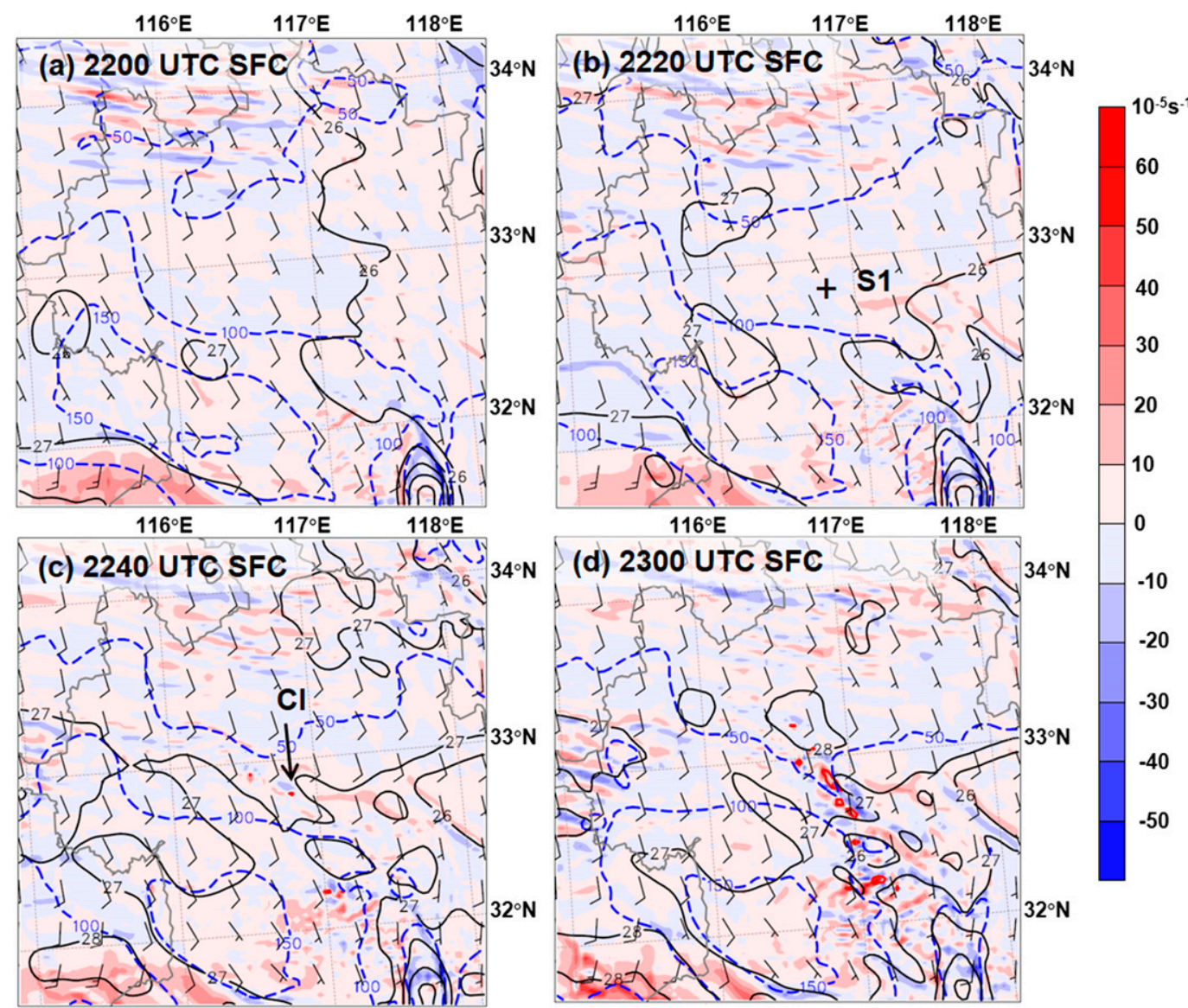

FIG. 9. Divergence (shaded every $10^{-4} \mathrm{~s}^{-1}$; blue for convergence and red for divergence), CIN (contoured in dashed blue every $50 \mathrm{~J} \mathrm{~kg}^{-1}$ ), and horizontal wind vector (barb $=5 \mathrm{~m} \mathrm{~s}^{-1}$, half barb $=2.5 \mathrm{~m} \mathrm{~s}^{-1}$ ) at the bottom model level, surface temperature (contoured in solid black every $1^{\circ} \mathrm{C}$ ), and $35-\mathrm{dBZ}$ contour of composite radar reflectivity (solid red) in the control simulation at (a) 2200 UTC, (b) 2220 UTC, (c) 2240 UTC, and (d) 2300 UTC 22 Jun. The first convective cell reaching $35 \mathrm{dBZ}$ is denoted in (c) as CI. The location of S1 given in (b) is the same as in Fig. 7a.

Yonsei State University PBL scheme (YSU; Hong et al. 2006), and the Rapid Radiative Transfer Model (RRTM) longwave radiation scheme (Mlawer et al. 1997) were used for all three domains. The GrellDevenyi ensemble cumulus scheme (Grell and Devenyi 2002) was used for D01 and D02. No cumulus parameterization was used for D03. In addition, a 10-member ensemble forecast was performed with the same physical parameterization schemes and domains as the control simulation. The ensemble was generated by adding perturbations randomly sampled from the default background error covariance of "cv3" in the WRF threedimensional variational data assimilation system (3DVar; Barker et al. 2004), similar to Meng and Zhang (2007, 2008a, b, 2011). The domain-averaged standard deviations of perturbed variables $\left(0.56 \mathrm{~m} \mathrm{~s}^{-1}\right.$ for $u$ and $v$, $0.10 \mathrm{~g} \mathrm{~kg}^{-1}$ for $q_{v}, 0.25 \mathrm{~K}$ for $T$, and $11 \mathrm{~Pa}$ for $p^{\prime}$ ) were much smaller than the observational uncertainties.

\section{b. CI in the control simulation}

The control simulation successfully captured the initiation of the linear MCS and the near-CI environment with acceptable timing and location errors. Following widely used CI definitions based on radar observations (e.g., Kingsmill 1995; Weckwerth 2000; Roberts and Rutledge 2003; Huang et al. 2017), in the current study, CI was defined when radar echo first reached $35 \mathrm{dBZ}$, which then developed into a linear MCS. A weak echo of $10 \mathrm{dBZ}$ appeared at 2220 UTC 22 June (Fig. 7a) and reached $35 \mathrm{dBZ}$ at $2240 \mathrm{UTC}$ (Fig. 7b), which represented the initiation of convection. Newly initiated convective cells merged together as they moved northeastward (Figs. 7c-e) and gradually developed into a northwest-southeast-oriented convective line (Fig. 7f) similar to the observations (Fig. 2e). In addition, the simulated sounding profile S2 (Fig. 8b, location denoted 

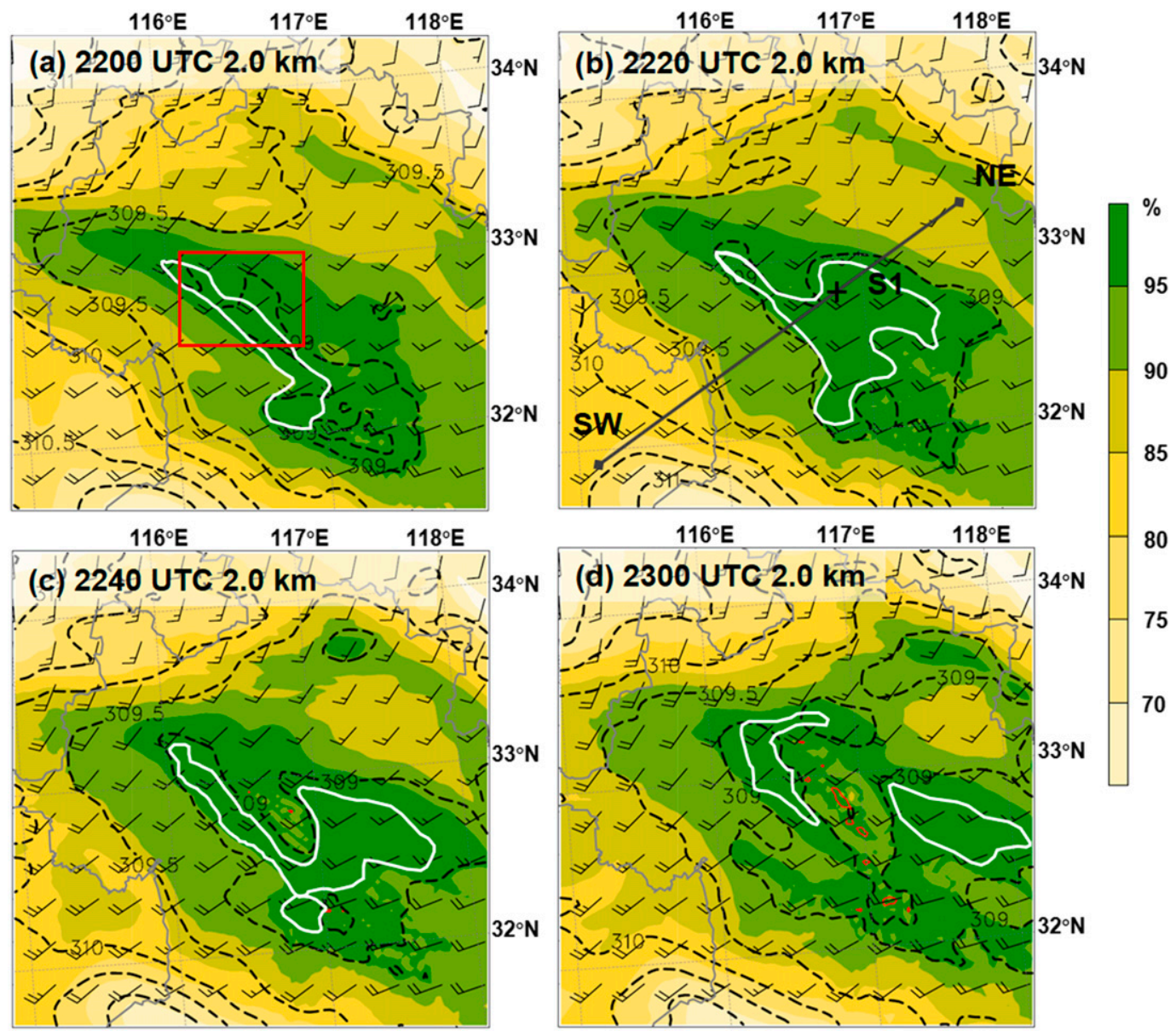

FIG. 10. Relative humidity (shaded every $5 \%$ ), $0.5 \mathrm{~J} \mathrm{~kg}^{-1} \mathrm{CIN}$ (contoured in white), horizontal wind vector $\left(\right.$ barb $=5 \mathrm{~m} \mathrm{~s}^{-1}$, half barb $\left.=2.5 \mathrm{~m} \mathrm{~s}^{-1}\right)$, and potential temperature (contoured in dash black every $\left.0.5 \mathrm{~K}\right)$ at $2.0 \mathrm{~km}$ AGL and the $35-\mathrm{dBZ}$ contour (solid red) of composite radar reflectivity (solid red) in the control simulation at (a) 2200 UTC, (b) 2220 UTC, (c) 2240 UTC, and (d) 2300 UTC 22 Jun. The location of S1 is the same as in Fig. 7a, and the cross section in Fig. 11a and Fig. 13 is given in (b). The red box denotes the area used for diagnosing the area-averaged transport of water vapor mixing ratio and potential temperature in Fig. 14.

in Fig. 7f) at 0000 UTC 23 June located upstream of the linear MCS closely resembled the Fuyang sounding (Fig. 5a). A prominent near-surface temperature inversion and an elevated saturated layer $(679-628 \mathrm{hPa})$ were revealed by $\mathrm{S} 2$ in the simulation (Fig. 8b). The surface-based CAPE at S2 was $1538 \mathrm{~J} \mathrm{~kg}^{-1}$, and the inversion near the surface resulted in a surface-based CIN of $115 \mathrm{~J} \mathrm{~kg}^{-1}$. Similar to the Fuyang sounding, the elevated saturated layer greatly reduced the CIN of the parcel lifted above the stable boundary layer (e.g., $12 \mathrm{~J} \mathrm{~kg}^{-1}$ at $850 \mathrm{hPa}$ ). The CI timing in the control simulation was approximately $1 \mathrm{~h}$ later than that in the observation, and the CI location was approximately $100 \mathrm{~km}$ east of the observation. However, considering the limitations of convection-permitting models in predicting the timing and location of pristine elevated CIs shown by Stelten and Gallus (2017) and the similar convection morphology between simulation and observation during the $\mathrm{CI}$, we believe that this simulation can reasonably be used to investigate $\mathrm{CI}$ mechanisms.

Similar to the observation, the simulated surface environment was unfavorable for surface-based CI. The simulated CI occurred within the weak uniform southerlies, and the surface temperature gradient was rather small before the CI (Figs. 9a,b). The magnitude of divergence on the bottom model level was less than $1 \times 10^{-4} \mathrm{~s}^{-1}$, which was much weaker than the convergence in a surface-based CI environment [e.g., $5 \times$ $10^{-4} \mathrm{~s}^{-1}$ in Su and Zhai (2017)], indicating the absence of strong updrafts near the surface. Considering the weak near-surface lifting and the surface-based CIN of $50-100 \mathrm{~J} \mathrm{~kg}^{-1}$ that resulted from the temperature inversion near the surface, the convection could hardly originate from the surface. Because of the diurnal variation and 
(a) $\frac{\partial \theta_{e}}{\partial z}$ and 4-h back trajectories

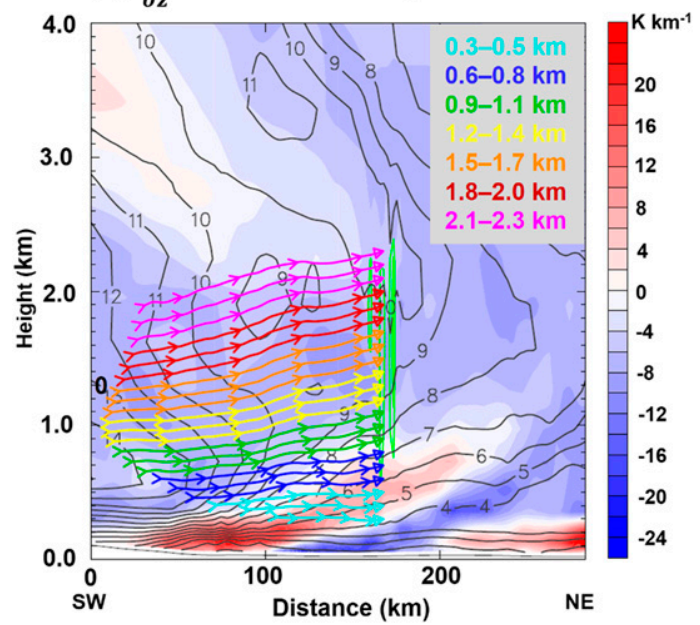

(b) 2.0-km RH \& $\theta$ and 4-h back trajectories

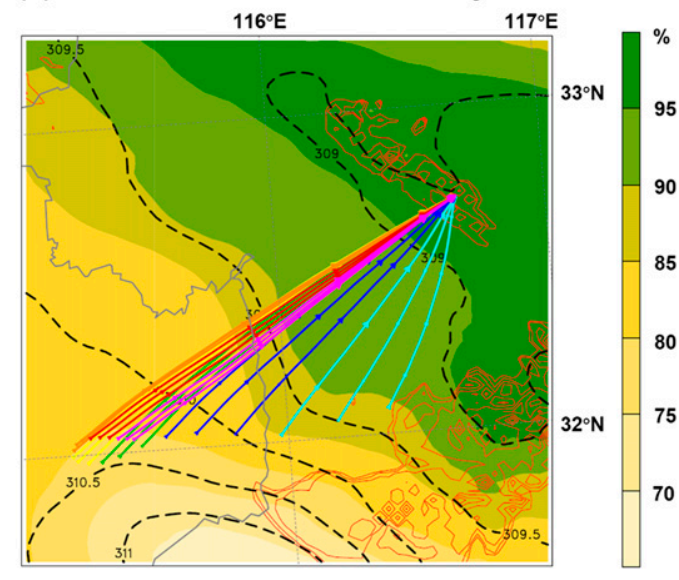

FIG. 11. (a) Vertical distributions of 4-h back trajectories of parcels released from the 10-dB $Z$ radar echo at 2220 UTC 22 Jun with different heights (0.3-2.3 km AGL; colors correspond to different heights as shown in the top-right box) along the plane of the cross section in Fig. $10 \mathrm{~b}$; also shown are potential instability $\left(\partial \theta_{e} / \partial z\right.$, shaded every $2 \mathrm{~K} \mathrm{~km}^{-1}$ ), model-derived composite radar reflectivity (contoured in green at 5-dBZ intervals), and horizontal wind speed along the plane of the cross section (contoured in solid black every $1 \mathrm{~m} \mathrm{~s}^{-1}$ ) at 2220 UTC 22 Jun. (b) Horizontal distributions of the same parcel trajectories as in (a); also shown are relative humidity (shaded at $5 \%$ intervals), model-derived composite radar reflectivity (contoured in red at 5 -dBZ intervals), and potential temperature (contoured in black dashes every $0.5 \mathrm{~K}$ ) at $2.0 \mathrm{~km}$ AGL at 2220 UTC 22 Jun.

the weakened temperature inversion, CIN reduced slightly at 2240 UTC 22 June (Fig. 9c, CI timing) but was still $\sim 50 \mathrm{~J} \mathrm{~kg}^{-1}$. Surface cold pools are often associated with surface-based convection initiation (Weckwerth and Parsons 2006), but in the present case, no strong cold pool was observed near the surface even 20 min after the CI (Fig. 9d). All the evidences suggested that the initiation in this case was elevated.

The simulated sounding at the CI location $20 \mathrm{~min}$ before the CI (S1 at 2220 UTC denoted in Fig. 7a) revealed a MAUL with a depth of $30 \mathrm{hPa}$ (between 809 and $778 \mathrm{hPa}$, $\sim 2.0 \mathrm{~km} \mathrm{AGL}$ ) and a lapse rate of $6.4 \mathrm{~K} \mathrm{~km}^{-1}$ (Fig. 8a), which was greater than the moist adiabatic lapse rate. The vertical velocity averaged within the MAUL over the red box denoted in Fig. 10a was $2.60 \mathrm{~cm} \mathrm{~s}^{-1}$, which was broadly consistent with the weak vertical motion of -3 to $-10 \mu \mathrm{bs}^{-1}$ at low levels observed in Trier et al. (2017). In S1, the parcel lifted from the base of the MAUL $(809 \mathrm{hPa})$ had a CAPE of $748 \mathrm{~J} \mathrm{~kg}^{-1}$ and an approximately negligible CIN (Fig. 8a). Based on parcel theory, this indicates that weak and even imperceptible updrafts within the MAUL could overcome the CIN and release the conditional instability. At the altitude of the MAUL ( $\sim 2.0 \mathrm{~km}$ AGL), there was a northwest-southeastoriented nearly saturated (relative humidity greater than $95 \%$ ) band at 2200 UTC 22 June perpendicular to the strong low-level southwesterly winds (Fig. 10a). This elevated nearly saturated band resulted in a narrow area with negligible CIN (magnitude smaller than $0.5 \mathrm{~J} \mathrm{~kg}^{-1}$, white contour) with a length of $\sim 150 \mathrm{~km}$. The elevated nearly saturated band expanded at 2220 UTC, which led to a wider area with negligible CIN (Fig. 10b). Several convective cells were initiated in this area at 2240 UTC (Fig. 10c), and the associated nearly saturated band gradually broke up due to the condensation from the convection (Fig. 10d).

Back trajectories of parcels released from the location of the first $10-\mathrm{dB} Z$ echo at 2220 UTC at altitudes between 0.3 and $2.3 \mathrm{~km}$ AGL were computed for $4 \mathrm{~h}$ using the 5-min-resolution model output from the control simulation (Fig. 11). Trajectories above $\sim 1 \mathrm{~km}$ AGL were characterized as having sloping mesoscale ascent, whereas there was no obvious lifting in near-surface trajectories, which reconfirmed that the convection did not originate from the surface. Moreover, the horizontal distribution of the trajectories revealed that the southwesterly winds were mainly above $\sim 1 \mathrm{~km}$ AGL, while the near-surface trajectories were more southerly, which was corroborated by the observation (Fig. 1b and Fig. 4a).

The difference between 1-2.3 km AGL and 0.3-1 km AGL trajectories (Fig. 11a) resulted in distinct evolutions of the diagnostic variables along the trajectories. CIN along the trajectories above $1 \mathrm{~km}$ AGL gradually decreased to negligible values as the CI was approached, 

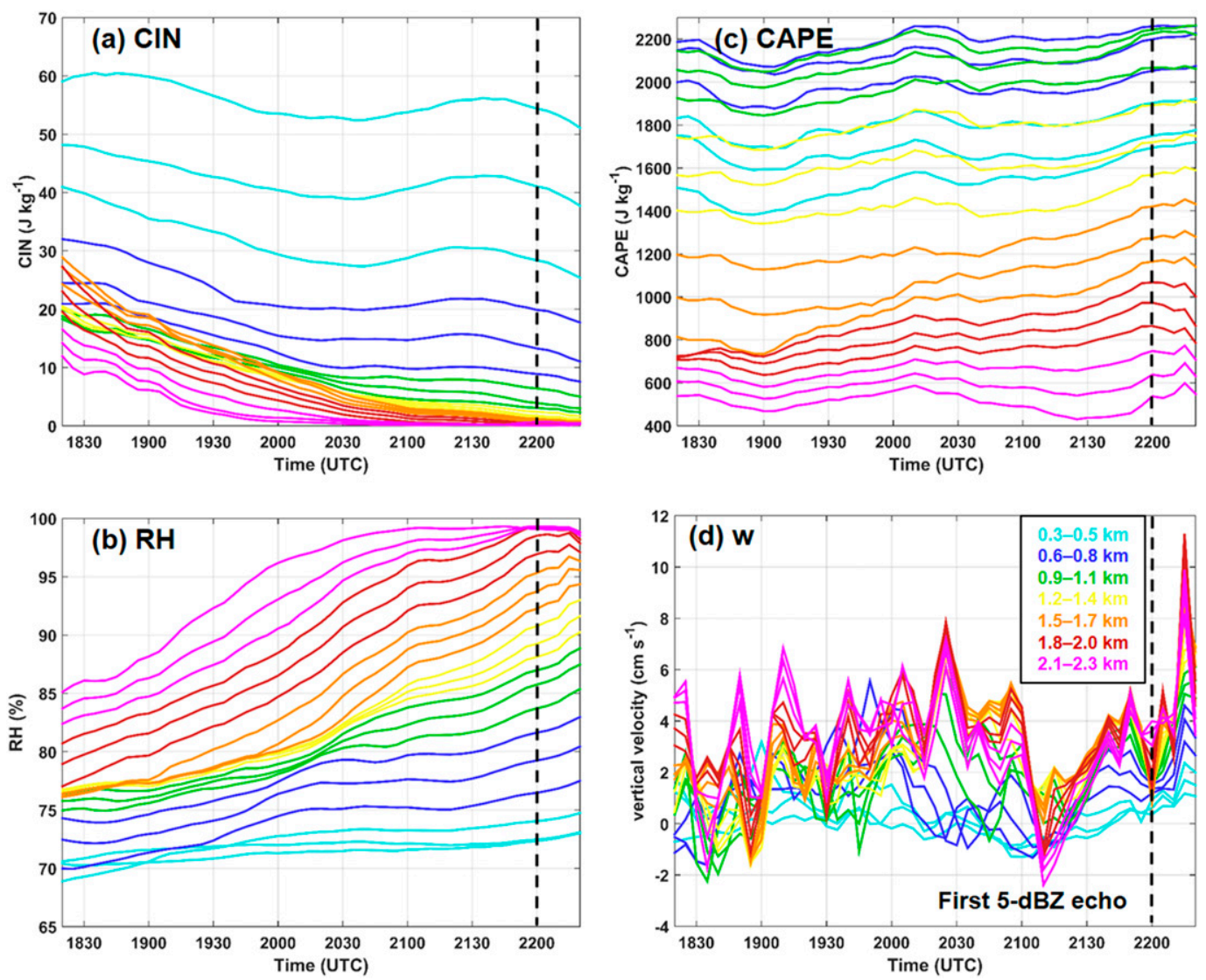

FIG. 12. (a) CIN $\left(\mathrm{J} \mathrm{kg}^{-1}\right)$, (b) relative humidity (\%), (c) CAPE $\left(\mathrm{J} \mathrm{kg}^{-1}\right)$, and (d) vertical velocity $\left(\mathrm{cm} \mathrm{s}^{-1}\right)$ along the color-coded trajectories plotted in Fig. 11a. The black dashed line indicates the time (2200 UTC 22 Jun) when the first 5-dBZ echo appeared.

while the CIN along near-surface trajectories only slightly decreased (Fig. 12a). For example, the CIN along the $1.7-\mathrm{km}$ trajectory decreased from $30 \mathrm{~J} \mathrm{~kg}^{-1}$ to approximately $0 \mathrm{~J} \mathrm{~kg}^{-1}$ during the $4 \mathrm{~h}$ before $\mathrm{CI}$, which suggests the formation of an elevated MAUL; however, the CIN along the $0.3-\mathrm{km}$ AGL trajectory decreased only from 60 to $50 \mathrm{~J} \mathrm{~kg}^{-1}$ (Fig. 12a). The increase in relative humidity was broadly consistent with the decrease in CIN. During 2020-2220 UTC, the relative humidity along trajectories between $1.2-2.3 \mathrm{~km}$ AGL rapidly increased to near saturation (over $90 \%$ ), while the near-surface relative humidity slightly increased but remained unsaturated (Fig. 12b). During the $4 \mathrm{~h}$ prior to CI, CAPE along most trajectories slightly increased (Fig. 12c), indicating the relatively steady conditional instability before CI.

Notably, although the mesoscale vertical motion generally increased with height (Fig. 12d), the vertical velocity along trajectories did not vary monotonically with time as did other diagnostic variables. The vertical velocity varied between -2 and $10 \mathrm{~cm} \mathrm{~s}^{-1}$ without identifiable patterns, which indicated that the updraft underwent no regular change as initial convection was approached (before 2200 UTC). Without obvious lifting mechanisms, CI seemed to be more dependent on the thermodynamic field that was becoming increasingly conducive to CI. Given sufficient conditional instability, CI could be largely dependent on the formation of the elevated MAUL.

\section{c. Formation mechanisms and characteristics of MAUL}

The formation of the elevated MAUL was further examined on a vertical cross section taken along the lowlevel southwesterly winds perpendicular to the linear MCS (cross-sectional path shown in Fig. 10b). The horizontal wind speed field along the cross section featured a typical LLJ structure (Fig. 13a). There was cooling of $\sim-0.6 \mathrm{~K}$ between 2 and $3 \mathrm{~km}$ AGL, possibly related to the weak lifting (vertical velocity of $\sim 5 \mathrm{~cm} \mathrm{~s}^{-1}$ ) near the terminus of the LLJ. The cooling increased and extended both upward and downward as the LLJ between 2 and $3 \mathrm{~km}$ AGL intensified (Fig. 13b). Moreover, the high-moisture area signified by the surge of the equivalent potential temperature $\theta_{e}$ near $2.0 \mathrm{~km}$ AGL was also gradually moving northeastward (Figs. 13c,d). 

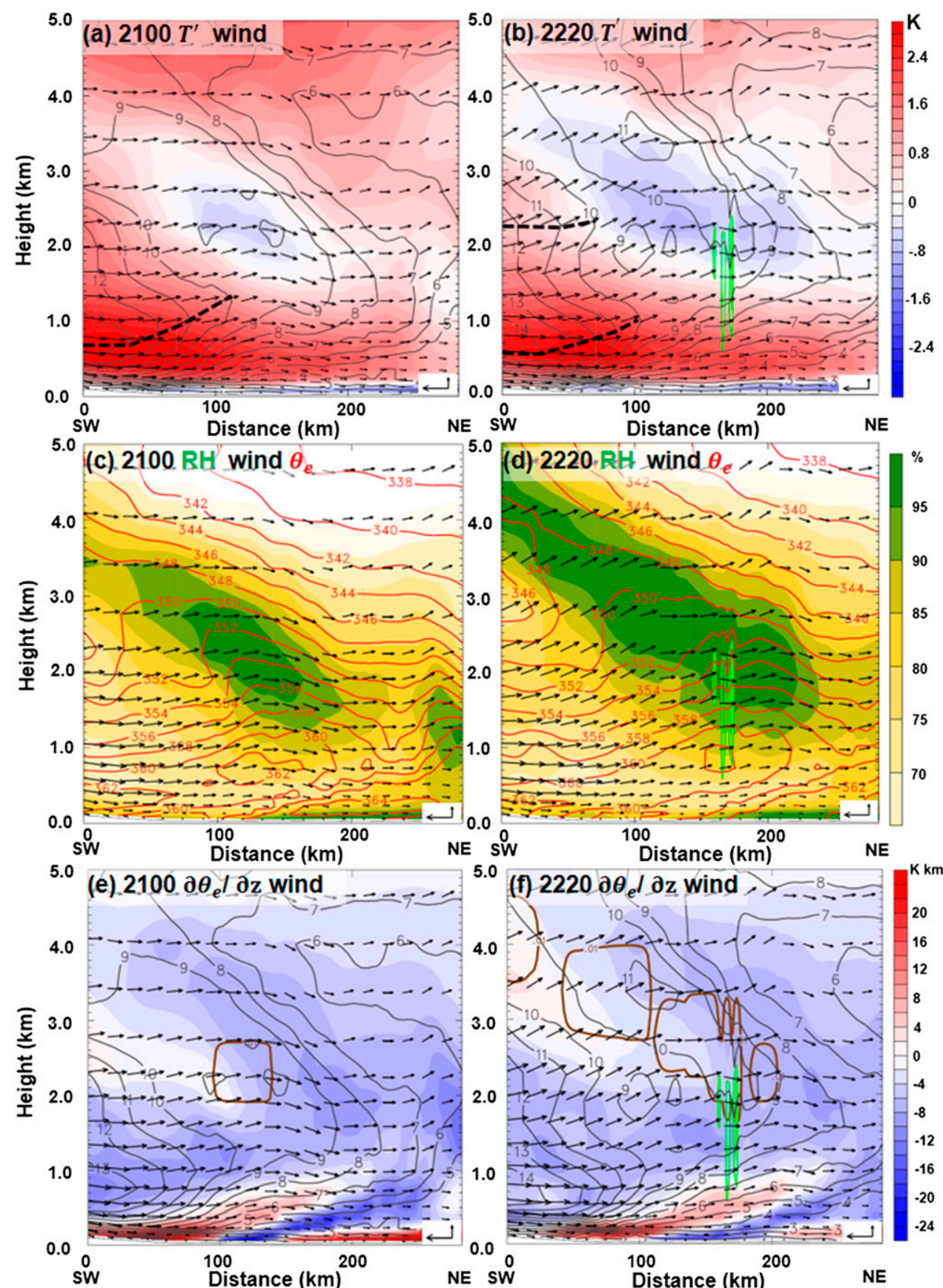

FIG. 13. Vertical cross sections along the SW-NE transect in Fig. 10b of (top) temperature perturbation (shaded at $0.2-\mathrm{K}$ intervals), model-derived radar reflectivity (contoured in green at 5-dBZ intervals), horizontal wind speed along the plane of the cross section (contoured in solid black every $1 \mathrm{~m} \mathrm{~s}^{-1}$ ), and circulation vectors in the plane of the cross section at (a) 2100 UTC and (b) 2220 UTC 22 Jun; the reference state used to compute the temperature perturbation has the same lapse rate $\left(0.0065 \mathrm{~K} \mathrm{~m}^{-1}\right.$ below $\left.11 \mathrm{~km}\right)$ as the U.S. Standard Atmosphere and a sea level temperature of $301 \mathrm{~K}$ from this current case. (middle) The relative humidity (shaded at $5 \%$ intervals), model-derived radar reflectivity (contoured in green at 5-dBZ intervals), equivalent potential temperature (contoured in red every $2 \mathrm{~K}$ ), and circulation vectors in the plane of the cross section at (c) 2100 UTC and (d) 2220 UTC 22 Jun. (bottom) The potential instability $\left(\partial \theta_{e} / \partial z\right.$, shaded every $\left.2 \mathrm{~K} \mathrm{~km}^{-1}\right)$, model-derived radar reflectivity (contoured in green at 5-dBZ intervals), cloud water mixing ratio $\left(0.01 \mathrm{~g} \mathrm{~kg}^{-1}\right.$ contour in solid brown), horizontal wind speed along the plane of the cross section (contoured in solid black every $1 \mathrm{~m} \mathrm{~s}^{-1}$ ), and circulation vectors in the plane of the cross section at (e) 2100 UTC and (f) 2220 UTC 22 Jun. The reference vector is given at the bottom right and denotes a horizontal velocity of $10 \mathrm{~m} \mathrm{~s}^{-1}$ and a vertical velocity of $10 \mathrm{~cm} \mathrm{~s}^{-1}$. The jet axes of the LLJ mentioned in the text are qualitatively denoted by the bold black dashed lines in (a) and (b). 
The saturated ${ }^{2}$ layer located in the potential unstable environment (Figs. 13e,f) indicated the existence of the elevated MAUL, especially when the initial convection was still absent (at 2100 UTC in Fig. 13e). This suggested that the elevated MAUL in the current case was an important precondition for initial convection rather than simply the result of the convection. Both the cooling and the moisture surge near the terminus of the LLJ contributed to the formation of MAUL, and convective cells were eventually generated in the elevated MAUL (Figs. 13b,d).

The contributions to the formation of the elevated MAUL from the budget of thermodynamic variables were quantitatively diagnosed by using equations of potential temperature and water vapor mixing ratio:

$$
\begin{gathered}
\frac{\partial \theta}{\partial t}=-\mathbf{V} \cdot \nabla_{h} \theta-w \frac{\partial \theta}{\partial z}+D_{\theta}, \\
\frac{\partial q_{v}}{\partial t}=-\mathbf{V} \cdot \nabla_{h} q_{v}-w \frac{\partial q_{v}}{\partial z}+D_{q_{v}},
\end{gathered}
$$

where $D_{\theta}$ and $D_{q_{v}}$ are the diabatic forcing terms of potential temperature and water vapor mixing ratio, respectively. All terms in the equations were averaged horizontally over the domain indicated by the red box in Fig. 10a and vertically over model levels within the MAUL shown in Fig. 8a. Since the magnitude of the adiabatic term (sum of horizontal and vertical transport) was much larger than the diabatic term in both equations (Fig. 14), the thermodynamic process was nearly adiabatic in most of the time prior to CI (e.g., from 2120 to 2200 UTC). During the 1-h period before the first 10-dBZ echo appeared (2120-2220 UTC), there was a potential temperature decrease of $0.47 \mathrm{~K}$ (not shown), a water vapor increase of $0.47 \mathrm{~g} \mathrm{~kg}^{-1}$ (not shown) and a relative humidity increase from $92 \%$ to $97.5 \%$ (Fig. 14b). During 2120-2140 UTC, horizontal advection of potential temperature was the main contributor to the local cooling, while the vertical transport of potential temperature became stronger than the horizontal advection of potential temperature after 2140 UTC as the layer became saturated (Fig. 14a). In the local change of moisture (Fig. 14b), the horizontal advection of water vapor outweighed the vertical transport most of the time (until 2200 UTC), during which the relative humidity rapidly increased, which indicated that the local moisture accumulation was mainly contributed by the horizontal moisture transport from upstream. This

\footnotetext{
${ }^{2}$ Following the metrics in Bryan and Fritsch (2000), a grid point is considered saturated if the cloud water mixing ratio exceeds $0.01 \mathrm{~g} \mathrm{~kg}^{-1}$.
}
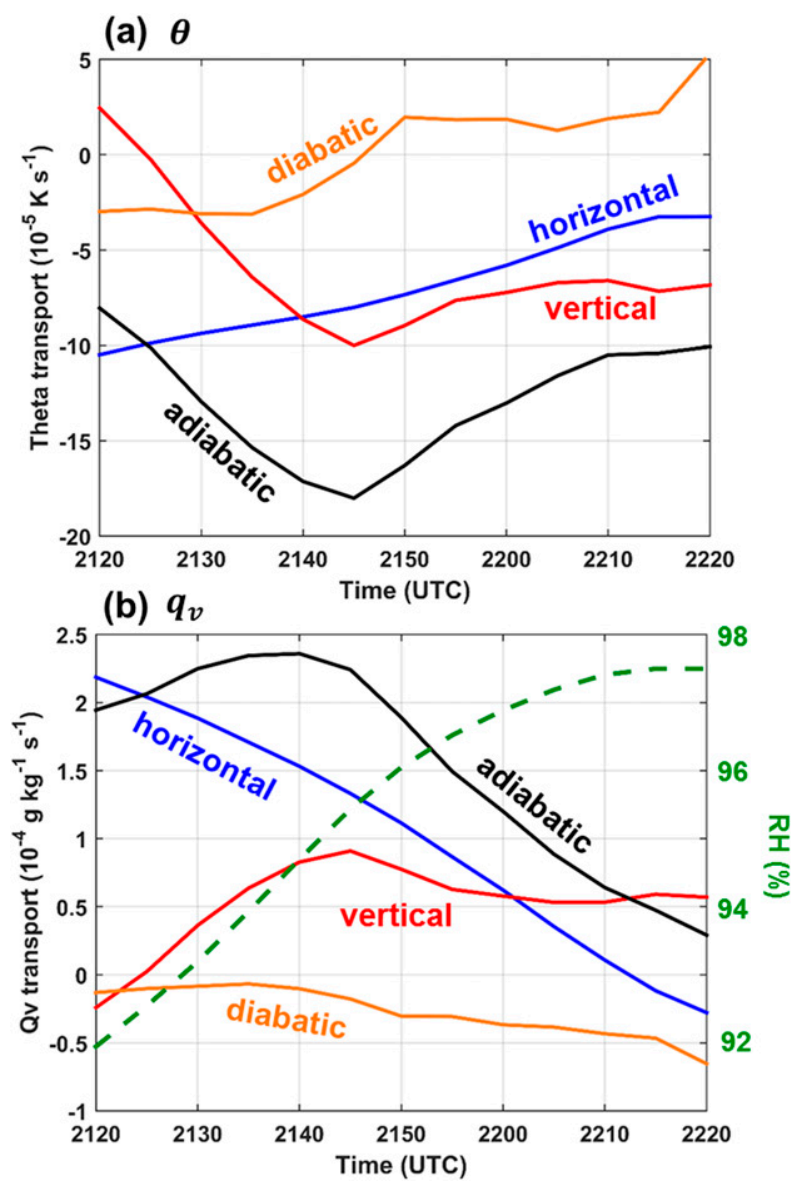

FIG. 14. (a) Evolution of the area-averaged horizontal advection $\left(-\mathbf{V} \cdot \nabla_{h} \theta\right.$, solid blue $)$, vertical transport $[-w(\partial \theta / \partial z)$, solid red], diabatic term $\left(D_{\theta}\right.$, solid orange), and adiabatic term $\left[-\mathbf{V} \cdot \nabla_{h} \theta-\right.$ $w(\partial \theta / \partial z)$, solid black] of potential temperature within the subsequent MAUL (unit: $10^{-5} \mathrm{~K} \mathrm{~s}^{-1}$ ) on 22 Jun. (b) As in (a), but for the water vapor mixing ratio (unit: $10^{-4} \mathrm{~g} \mathrm{~kg}^{-1} \mathrm{~s}^{-1}$ ). The evolution of the area-averaged relative humidity within the subsequent MAUL is also plotted as the dashed green line in (b). The area used for averaging is denoted as the red box in Fig. 10a.

result was somewhat different from cases in the U.S. plains (Trier et al. 2014) where the vertical moisture transport is typically more important in reducing negative buoyancy in the near inflow to convection than the horizontal moisture transport. During the mei-yu season in central-eastern China from mid-June to mid-July, the southwesterly LLJ often appears on the northwest edge of the subtropical high over the northwest Pacific Ocean (Tao and Chen 1987), transporting rich moisture mainly horizontally from the South China Sea or the East China Sea. It likely contains more moisture than the summertime LLJ air in the U.S. plains originating in a hotter and drier region which makes the U.S. cases require greater upward moisture transport to create a MAUL. To summarize, the adiabatic cooling from the weak vertical ascent 


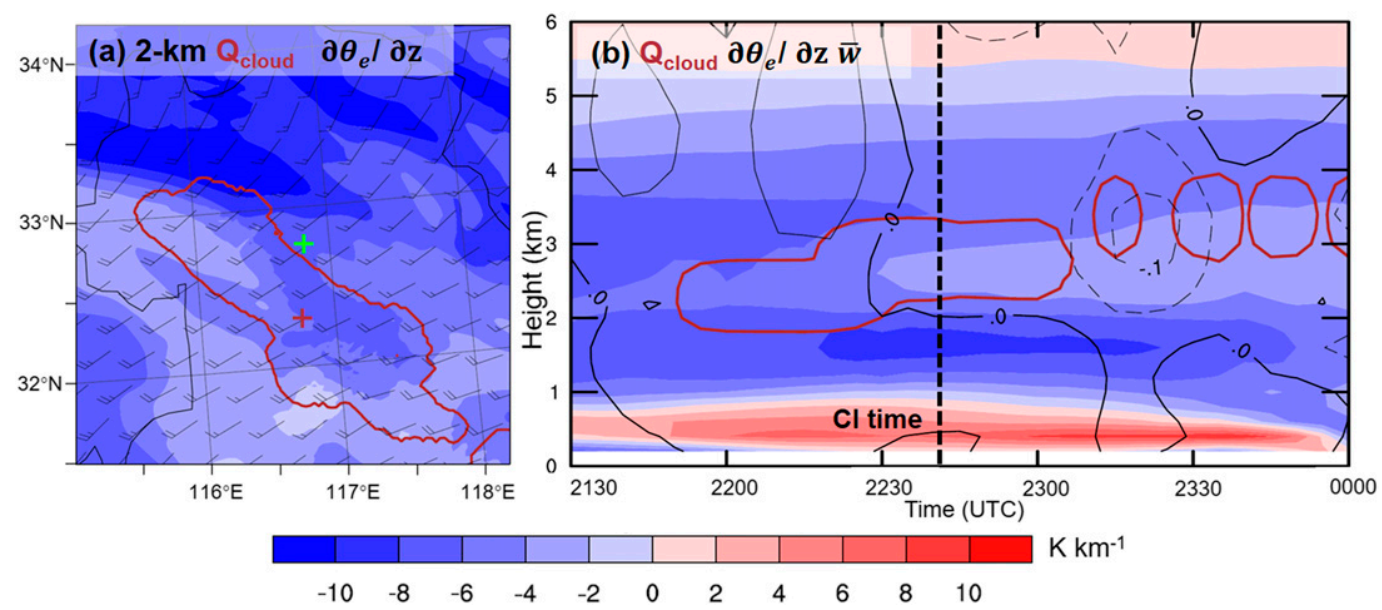

FIG. 15. Temporal and spatial scale of the simulated MAUL. (a) Potential instability $\left(\partial \theta_{e} / \partial z\right.$, shaded every $\left.2 \mathrm{~K} \mathrm{~km}^{-1}\right)$, cloud water mixing ratio $\left(0.01 \mathrm{~g} \mathrm{~kg}^{-1}\right.$ contour in solid brown), and horizontal wind vector (barb = $5 \mathrm{~m} \mathrm{~s}^{-1}$, half barb $=2.5 \mathrm{~m} \mathrm{~s}^{-1}$ ) at $2 \mathrm{~km} \mathrm{AGL}$ at 2200 UTC $22 \mathrm{Jun}$. The CI location (first 35-dBZ echo at 2240 UTC 22 Jun) is denoted by the green cross. (b) Time series of vertical conditions at the grid point denoted by the brown cross in (a), potential instability $\left(\partial \theta_{e} / \partial z\right.$, shaded every $\left.2 \mathrm{~K} \mathrm{~km}^{-1}\right)$, cloud water mixing ratio $\left(0.01 \mathrm{~g} \mathrm{~kg}^{-1}\right.$ contour in solid brown), and 20-min-averaged vertical velocity (contoured in solid black for positive and negative in black dashes every $0.05 \mathrm{~m} \mathrm{~s}^{-1}$ ). The CI timing (2240 UTC 22 Jun) is marked in black dashes in (b).

and the horizontal moisture transport mainly contributed to the formation of the elevated saturated layer in the current case.

Near the CI location, the layer between 1-2 km AGL was potentially unstable $\left(\partial \theta_{e} / \partial_{z}<0\right.$, Figs. 13e,f). The weak ascent within the layer was likely to facilitate the realization of the potential instability and eventually led to the formation of MAUL. The layer-lifting process related to the release of potential instability was also corroborated with the shallow stratiform clouds before CI observed in satellite images (Fig. 3). Moreover, the moist static unstable environment near CI (Figs. 13e,f) suggested that gravity waves or bores might not be lifting mechanisms.

Characteristics of the simulated MAUL in the weaklifting environment of the present case were quite different from those in deep and intense updraft. Figure 15a displays the horizontal distribution of the MAUL (a saturated ${ }^{3}$ layer within which $\theta_{e}$ decreases with height). At 2200 UTC on $2 \mathrm{~km}$ AGL, the MAUL extended horizontally for approximately $200 \mathrm{~km}$ in length and $50 \mathrm{~km}$ in width, with the same northwest-southeast orientation as the convective line that developed downstream later. The horizontal width of $50 \mathrm{~km}$ was comparable to that of the MAUL examined near the gust front induced by a squall line (Bryan and Fritsch 2000). However, the vertical scale of the MAUL in this weak-lifting environment was

\footnotetext{
${ }^{3}$ Following the metrics in Bryan and Fritsch (2000), a grid point is considered saturated if the cloud water mixing ratio exceeds $0.01 \mathrm{~g} \mathrm{~kg}^{-1}$.
}

quite different. Figure $15 \mathrm{~b}$ reveals the vertical thermodynamic conditions as the MAUL passed the grid point upstream of the CI location (the location of the grid point is denoted in Fig. 15a). The grid point was chosen upstream of the CI location to avoid the influence of strong updrafts associated with deep convection. The vertical distribution of $\partial \theta_{e} / \partial z$ reconfirmed the existence of the potential unstable layer above $1 \mathrm{~km} \mathrm{AGL}$ and the MAUL located between 2 and $3 \mathrm{~km}$ AGL. The MAUL depth of $1 \mathrm{~km}$ was much shallower than the MAUL depth in a strong-lifting environment, which is generally $\sim 3 \mathrm{~km}$ (Bryan and Fritsch 2000). Moreover, the lapse rate of temperature within the MAUL was -4 to $-6 \mathrm{~K} \mathrm{~km}^{-1}$ (not shown) and was weaker than the lapse rate of -5 to $-8 \mathrm{~K} \mathrm{~km}^{-1}$ near the gust front (Bryan and Fritsch 2000). With regard to the temporal scale, the MAUL persisted for nearly $80 \mathrm{~min}$ from 2150 to 2310 UTC on an individual grid (Fig. 15b), which was longer than the duration of $30-45 \mathrm{~min}$ in a strong-lifting environment (Bryan and Fritsch 2000). In the early stage of the MAUL, there was weak vertical ascent $\left(0-5 \mathrm{~cm} \mathrm{~s}^{-1}\right)$ within the MAUL, which might lead to the lifting of the saturated layer during 2220-2230 UTC. Subsequently, the vertical ascent became weaker and, as a result, the MAUL began to weaken with a smaller magnitude of the lapse rate of $\theta_{e}$ and eventually collapsed at 2310 UTC.

It is interesting that the MAUL could be sustained even without strong mesoscale ascent, which has been considered an essential factor in the maintenance of MAULs. Two factors were favorable for sustaining the MAUL in the present case. One is the sufficient 

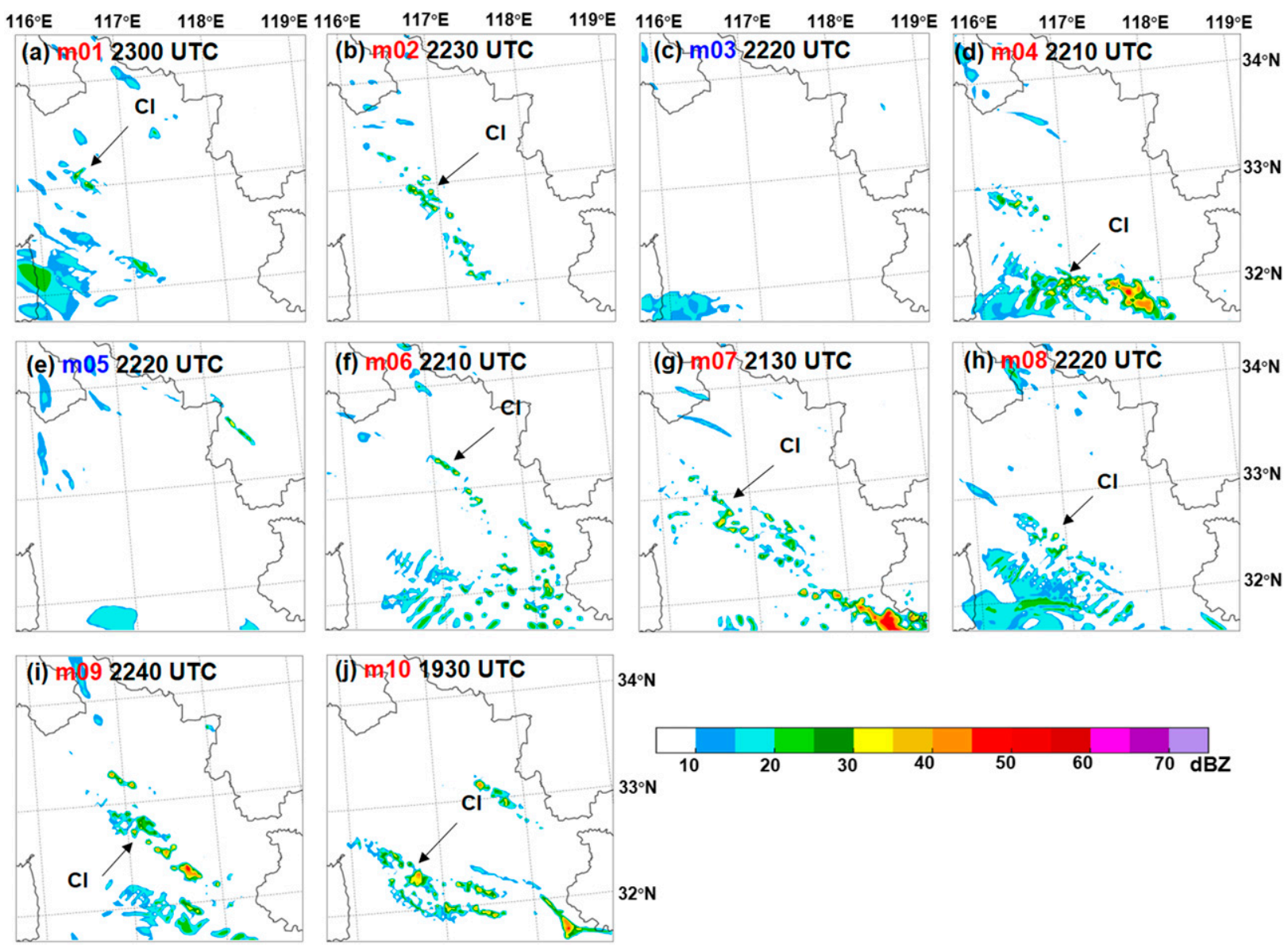

FIG. 16. (a)-(j) Model-derived (d03) composite radar reflectivity (shaded in dBZ) of the 10 ensemble members. CI members (red label) are plotted at respective CI timing, and non-CI members (blue label) are plotted at 2220 UTC 22 Jun for comparison.

horizontal moisture transport associated with the LLJ. The other is the small depth of the MAUL; a MAUL can be sustained only when the environmental mesoscale ascent generates instability faster than it can be removed by convective overturning as a result of buoyancy-driven velocity (Bryan and Fritsch 2000). Deeper MAULs, which induce a stronger buoyancy-driven vertical velocity, require stronger environmental vertical ascents to keep the MAULs from being destroyed (Barnes 2008). This behavior suggests that when the MAUL depth is shallow, weak vertical ascent will be sufficient to balance the buoyancy-driven vertical velocity and sustain the MAUL.

\section{d. CI predictability}

To understand the predictability of the elevated CI in the weak-lifting environment, the variability of CI timing and location in a 10-member ensemble forecast was examined. Similar to the CI definition mentioned in section $4 \mathrm{~b}$, for each ensemble member the CI timing for the target MCS was defined as the time when the radar echo first reached $35 \mathrm{~dB} Z$, which then developed into a contiguous or quasi-contiguous band of over $40-\mathrm{dB} Z$ reflectivity with a northwest-southeast orientation and a length of at least $50 \mathrm{~km}$ before 0130 UTC 23 June in the area of interest (the area of Fig. 16). The CI was reproduced in 8 out of 10 ensemble members (members 01, 02, 04, 06, 07, 08, 09, and 10), which indicated the high predictability $(80 \%)$ of $\mathrm{CI}$ in this case (Fig. 16). There was considerable variability in the timing and location of CI members. Including the control simulation, the CI timing ranged from 1930 UTC (member 10) to 2300 UTC (member 01), with a median of CI timing at 2220 UTC, and the CI location uncertainty was generally within $\sim 100 \mathrm{~km}$.

Whether having an elevated MAUL or not was the major difference between CI and non-CI members. At 20 min before CI timing, all CI members exhibited an elevated MAUL at $2 \mathrm{~km}$ AGL (Figs. 17a,b,d,f-j). The MAULs in CI members generally had a depth of $1 \mathrm{~km}$, similar to the control simulation, and persisted for 40-120 min on individual grids (not shown). These shallow but long-lasting MAULs in CI members were 

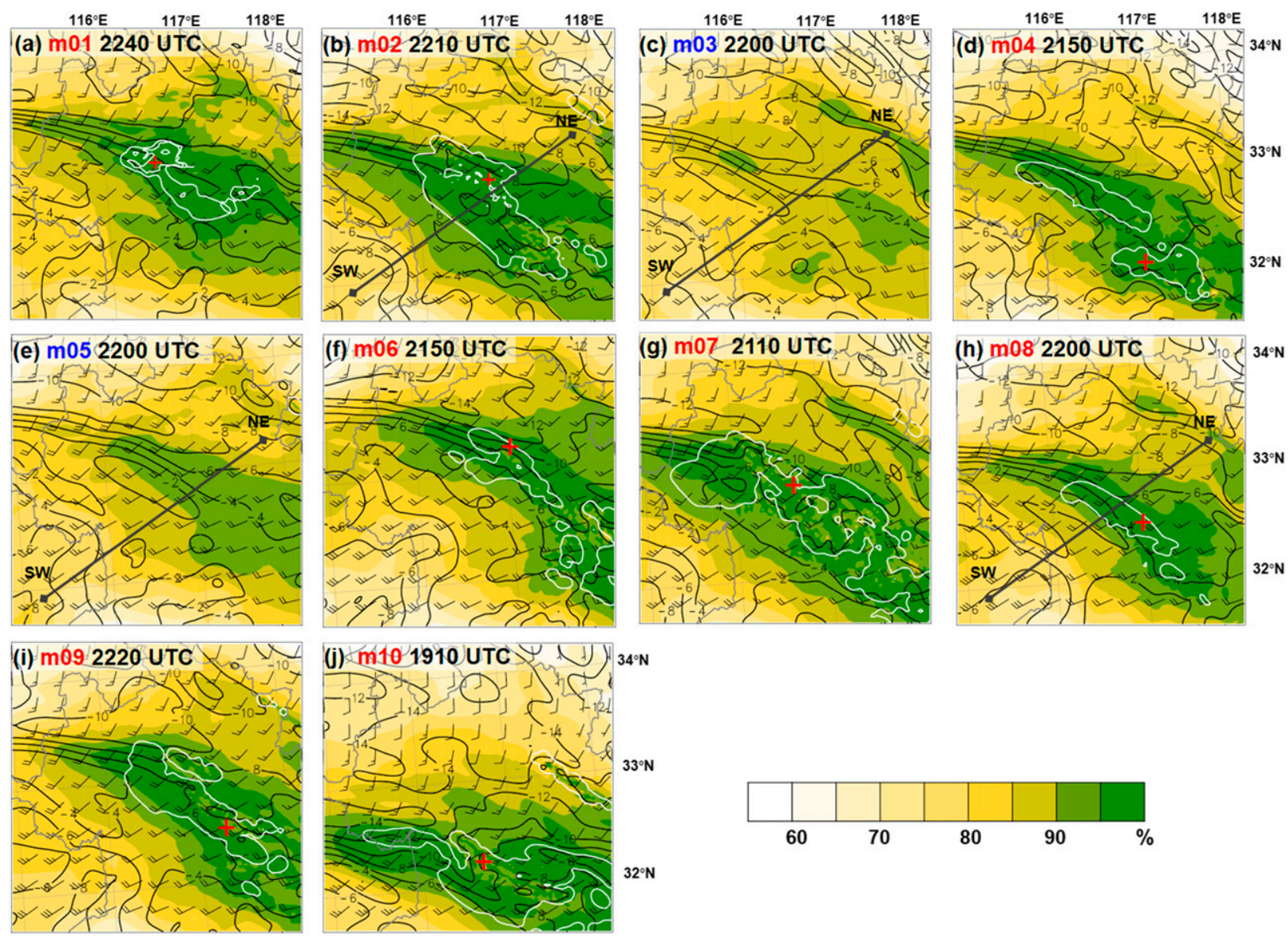

FIG. 17. (a)-(j) Distribution of elevated saturated area $20 \mathrm{~min}$ before CI including relative humidity (shaded every $5 \%$ ), horizontal wind vector (barb $=5 \mathrm{~m} \mathrm{~s}^{-1}$, half barb $\left.=2.5 \mathrm{~m} \mathrm{~s}^{-1}\right)$, potential instability $\left(\partial \theta e / \partial z\right.$, contoured in solid black every $\left.2 \mathrm{~K} \mathrm{~km}^{-1}\right)$, and cloud water mixing ratio (solid white, contours of $0.01 \mathrm{~g} \mathrm{~kg}^{-1}$ ) at $2.0 \mathrm{~km}$ AGL in 10 ensemble members. The solid black lines in (b), (c), (e), and (h) indicate the SW-NE path of the cross section in Fig. 18. The CI locations shown in Fig. 16 are marked as red crosses.

vastly important since CI could possibly occur at any location within the MAUL during its lifetime. In contrast, all of the non-CI ensemble members failed to produce MAULs (Figs. 17c and 17e). This finding supported the possibility that CI could be mainly determined by the existence of a MAUL. Strong finescale dynamic lifting may not be necessary in this elevated CI event. A comparison between typical CI members (members 02 and 08 ) with similar CI timing and non-CI members (member 03 and 05) (Fig. 18) showed that no obvious difference of vertical velocity in the general weak-lifting environment over the exit region of LLJ (approximately 1-3 km AGL, $50-170 \mathrm{~km}$ in southwest-northeast distance) could be identified to distinguish $\mathrm{CI}$ members from non-CI members.

\section{Summary}

This study investigated an elevated CI event in central-eastern China in the early morning on 23 June
2016. The CI occurred near the terminus of an LLJ in a weak-lifting environment far from a surface front. This elevated CI resulted in a linear MCS that gradually developed into a surface-based MCS and spawned an intensive supercell in the afternoon, which produced a severe EF4 tornado that killed 98 people.

Both observations and simulations suggested that this CI event was elevated and that the MAUL greatly facilitated CI by providing approximately negligible CIN. Surface observations and the sounding environment showed that there was no obvious surface boundary near CI locations and that the near-surface CIN was larger than that at $\sim 2 \mathrm{~km}$ above the ground due to the nearsurface temperature inversion at night and an elevated nearly saturated layer (MAUL). Back-trajectory analysis based on numerical simulation demonstrated the sloping ascent path before the onset of CI and reconfirmed that the convective updraft did not originate from the surface and the existence of weak vertical 

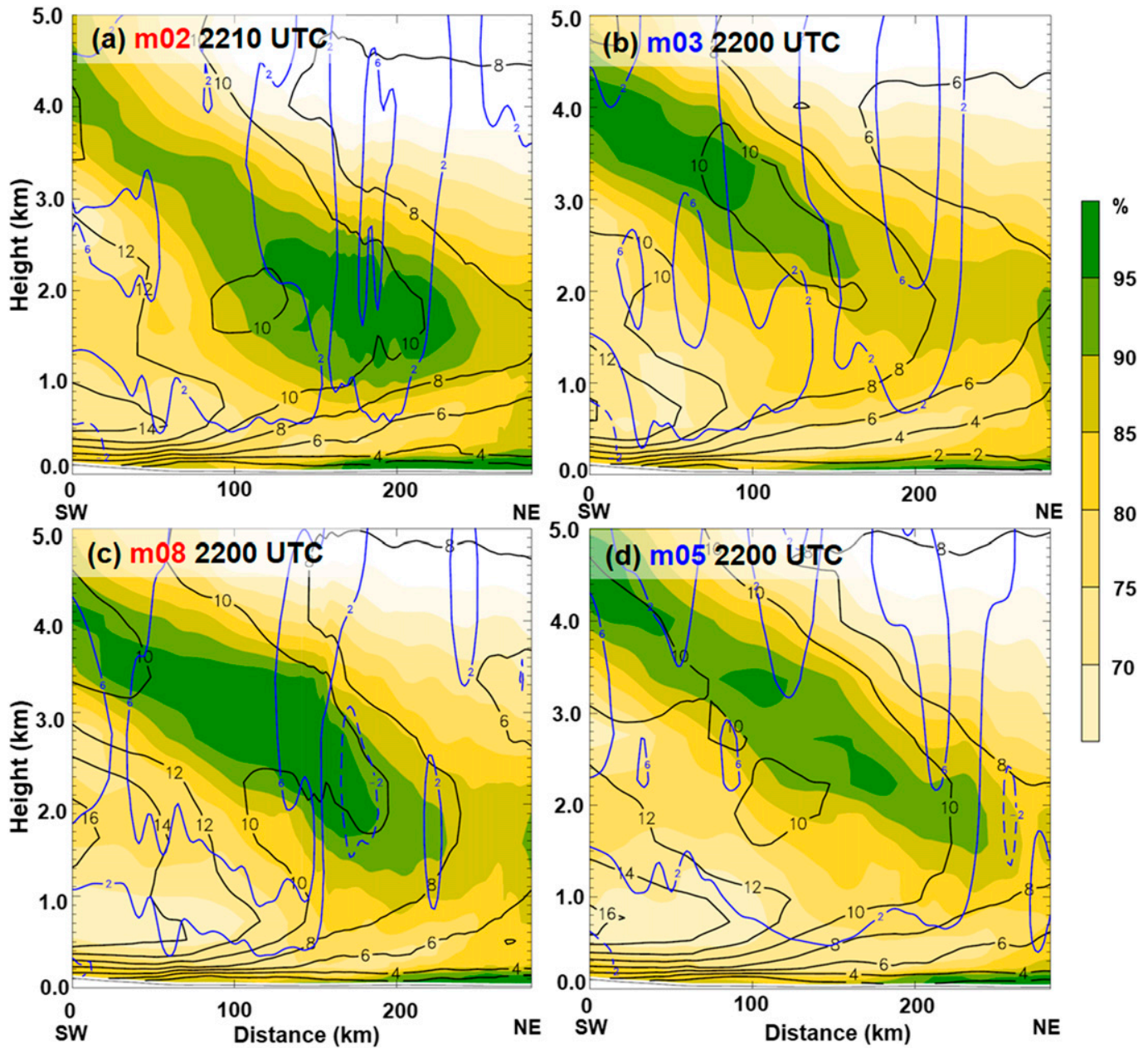

FIG. 18. Vertical cross sections along the SW-NE transect of typical CI and non-CI members in Figs. 17b, 17c, $17 \mathrm{e}$, and $17 \mathrm{~h}$, including relative humidity (shaded every $5 \%$ ), horizontal wind speed along the plane of the cross section (contoured in solid black every $2 \mathrm{~m} \mathrm{~s}^{-1}$ ), and 20-min-averaged vertical velocity [contoured in blue with positive $\left(>2 \mathrm{~cm} \mathrm{~s}^{-1}\right)$ in solid lines and negative $\left(<-2 \mathrm{~cm} \mathrm{~s}^{-1}\right)$ in dashes every $4 \mathrm{~cm} \mathrm{~s}^{-1}$ ] in (a) member 02 at 2210 UTC 22 Jun, (b) member 03 at 2200 UTC 22 Jun, (c) member 08 at 2200 UTC 22 Jun, and (d) member 05 at 2200 UTC 22 Jun.

ascent before the elevated CI. Along the parcel trajectories at low levels, CIN gradually decreased to negligible values and relative humidity increased nearly to saturation, which led to the formation of the elevated MAUL. However, the vertical velocity did not increase monotonically with time as CI was approached; rather, it was quite weak (lower than $12 \mathrm{~cm} \mathrm{~s}^{-1}$ ) and oscillated without an identifiable pattern. This condition suggested that the CI was more likely determined by the formation of the elevated MAUL than by the evolution of vertical velocity.

The formation mechanisms and characteristics of the MAUL in this case were investigated using numerical simulations. The elevated saturation was promoted by moisture surge and cooling near the LLJ terminus. Specifically, the increase in moisture was mainly contributed by horizontal moisture transport associated with the LLJ, while the cooling was mainly from adiabatic cooling associated with weak vertical motion rather than horizontal transport of potential temperature. Compared with MAULs in strong-lifting environments, the simulated MAUL in this weak-lifting environment had a shallower depth of $1 \mathrm{~km}$, a much weaker vertical ascent of $0-5 \mathrm{~cm} \mathrm{~s}^{-1}$, a weaker lapse rate of temperature of -4 to $-6 \mathrm{~K} \mathrm{~km}^{-1}$, and a longer duration of $80 \mathrm{~min}$. The shallow depth of the MAUL and the sufficient horizontal moisture transport were substantial factors in sustaining the MAUL in the weak-lifting environment.

The predictability of this elevated CI in the weaklifting environment was investigated using a 10-member ensemble forecast with an ensemble spread much smaller than the observational error. The probability of CI was 
approximately $80 \%$. The elevated MAUL, which was generally long lasting, was possibly a decisive condition for the CI in this event.

Acknowledgments. This work was sponsored by the National Natural Science Foundation of China (Grants 41425018 and 41875051) and the Ministry of Science and Technology of China (Grant 2013CB430104).

\section{REFERENCES}

Barker, D. M., W. Huang, Y.-R. Guo, A. J. Bourgeois, and Q. N. Xiao, 2004: A three-dimensional variational data assimilation system for MM5: Implementation and initial results. Mon. Wea. Rev., 132, 897-914, https://doi.org/10.1175/1520-0493(2004)132<0897: ATVDAS $>2.0 . \mathrm{CO} ; 2$.

Barnes, G. M., 2008: Atypical thermodynamic profiles in hurricanes. Mon. Wea. Rev., 136, 631-643, https://doi.org/10.1175/ 2007MWR2033.1.

Bentley, M. L., and T. L. Mote, 1998: A climatology of derechoproducing mesoscale convective systems in the central and eastern United States, 1986-95. Part I: Temporal and spatial distribution. Bull. Amer. Meteor. Soc., 79, 2527-2540, https:// doi.org/10.1175/1520-0477(1998)079<2527:ACODPM>2.0.CO;2.

Bryan, G. H., 2005: Spurious convective organization in simulated squall lines owing to moist absolutely unstable layers. Mon. Wea. Rev., 133, 1978-1997, https://doi.org/10.1175/MWR2952.1.

— and J. M. Fritsch, 2000: Moist absolute instability: The sixth static stability state. Bull. Amer. Meteor. Soc., 81, 1207-1230, https://doi.org/10.1175/1520-0477(2000)081<1287:MAITSS> 2.3.CO;2

Carbone, R. E., J. D. Tuttle, D. A. Ahijevych, and S. B. Trier, 2002: Inferences of predictability associated with warm season precipitation episodes. J. Atmos. Sci., 59, 2033-2056, https:// doi.org/10.1175/1520-0469(2002)059<2033:IOPAWW>2.0.CO;2.

Chen, H., R. Yu, J. Li, W. Yuan, and T. Zhou, 2010: Why nocturnal long-duration rainfall presents an eastward-delayed diurnal phase of rainfall down the Yangtze River Valley. J. Climate, 23, 905-917, https://doi.org/10.1175/2009JCLI3187.1.

Colman, B. R., 1990: Thunderstorms above frontal surfaces in environments without positive CAPE. Part I: A climatology. Mon. Wea. Rev., 118, 1103-1121, https://doi.org/10.1175/ 1520-0493(1990)118<1103:TAFSIE > 2.0.CO;2.

Corfidi, S. F., S. J. Corfidi, and D. M. Schultz, 2008: Elevated convection and castellanus: Ambiguities, significance, and questions. Wea. Forecasting, 23, 1280-1330, https://doi.org/ 10.1175/2008WAF2222118.1.

Davis, C. A., K. W. Manning, R. E. Carbone, S. B. Trier, and J. D. Tuttle, 2003: Coherence of warm-season continental rainfall in numerical weather prediction models. Mon. Wea. Rev., 131, 2667-2679, https://doi.org/10.1175/1520-0493(2003)131<2667: COWCRI $>2.0 . \mathrm{CO} ; 2$.

Degelia, S. K., X. Wang, D. J. Stensrud, and A. Johnson, 2018: Understanding the impact of radar and in situ observations on the prediction of a nocturnal convection initiation event on 25 June 2013 using an ensemble-based multiscale data assimilation system. Mon. Wea. Rev., 146, 1837-1859, https:// doi.org/10.1175/MWR-D-17-0128.1.

Du, Y., Q. Zhang, Y. Chen, Y. Zhao, and X. Wang, 2014: Numerical simulations of spatial distributions and diurnal variations of low-level jets in China during early summer.
J. Climate, 27, 5747-5767, https://doi.org/10.1175/JCLI-D13-00571.1.

Gebauer, J. G., A. Shapiro, E. Fedorovich, and P. Klein, 2018: Convection initiation caused by heterogeneous low-level jets over the Great Plains. Mon. Wea. Rev., 146, 2615-2637, https:// doi.org/10.1175/MWR-D-18-0002.1.

Geerts, B., and Coauthors, 2017: The 2015 Plains Elevated Convection at Night field project. Bull. Amer. Meteor. Soc., 98 , 767-786, https://doi.org/10.1175/BAMS-D-15-00257.1.

Grell, G. A., and D. Devenyi, 2002: A generalized approach to parameterizing convection combining ensemble and data assimilation techniques. Geophys. Res. Lett., 29, 1693, https:// doi.org/10.1029/2002GL015311.

He, Z., Q. Zhang, L. Bai, and Z. Meng, 2017: Characteristics of mesoscale convective systems in central East China and their reliance on atmospheric circulation patterns. Int. J. Climatol., 37, 3276-3290, https://doi.org/10.1002/joc.4917.

Hong, S.-Y., and J.-O. J. Lim, 2006: The WRF single-moment 6-class microphysics scheme (WSM6). J. Korean Meteor. Soc., 42, 129-151.

—, Y. Noh, and J. Dudhia, 2006: A new vertical diffusion package with an explicit treatment of entrainment processes. Mon. Wea. Rev., 134, 2318-2341, https://doi.org/10.1175/ MWR3199.1.

Huang, Y., Z. Meng, J. Li, W. Li, L. Bai, M. Zhang, and X. Wang, 2017: Distribution and variability of satellite-derived signals of isolated convection initiation events over central eastern China. J. Geophys. Res. Atmos., 122, 11357-11373, https:// doi.org/10.1002/2017JD026946.

Kingsmill, D. E., 1995: Convection initiation associated with a seabreeze front, a gust front, and their collision. Mon. Wea. Rev., 123, 2913-2933, https://doi.org/10.1175/1520-0493(1995)123<2913: CIAWAS $>2.0 . \mathrm{CO} ; 2$.

Kis, A. K., and J. M. Straka, 2010: Nocturnal tornado climatology. Wea. Forecasting, 25, 545-561, https://doi.org/10.1175/ 2009WAF2222294.1.

Koch, S. E., and C. O'Handley, 1997: Operational forecasting and detection of mesoscale gravity waves. Wea. Forecasting, 12, 253-281, https://doi.org/10.1175/1520-0434(1997)012<0253: OFADOM $>2.0 . \mathrm{CO} ; 2$.

Maddox, R. A., 1980: Mesoscale convective complexes. Bull. Amer. Meteor. Soc., 61, 1374-1387, https://doi.org/10.1175/ 1520-0477(1980)061<1374:MCC>2.0.CO;2.

Marsham, J. H., S. B. Trier, T. M. Weckwerth, and J. W. Wilson, 2011: Observations of elevated convection initiation leading to a surface-based squall-line during 13 June IHOP_2002. Mon. Wea. Rev., 139, 247-271, https://doi.org/10.1175/ 2010MWR3422.1.

Meng, Z., and F. Zhang, 2007: Tests of an ensemble Kalman filter for mesoscale and regional-scale data assimilation. Part II: Imperfect model experiments. Mon. Wea. Rev., 135, 14031423, https://doi.org/10.1175/MWR3352.1.

— , and - 2008a: Test of an ensemble Kalman filter for mesoscale and regional-scale data assimilation. Part III: Comparison with 3DVar for a real-data case study. Mon. Wea Rev., 136, 522-540, https://doi.org/10.1175/2007MWR2106.1.

$\longrightarrow$, and _ 2008b: Test of an ensemble Kalman filter for mesoscale and regional-scale data assimilation. Part IV: Comparison with 3DVar in a month-long experiment. Mon. Wea. Rev., 136, 3671-3682, https://doi.org/10.1175/2008MWR2270.1.

_ and - 2011: Limited-area ensemble-based data assimilation. Mon. Wea. Rev., 139, 2025-2045, https://doi.org/10.1175/ 2011MWR3418.1. 
D. Yan, and Y. Zhang, 2013: General features of squall lines in East China. Mon. Wea. Rev., 141, 1629-1647, https://doi.org/ 10.1175/MWR-D-12-00208.1.

— and Coauthors, 2018: The deadliest tornado (EF4) in the past 40 years in China. Wea. Forecasting, 33, 693-713, https:// doi.org/10.1175/WAF-D-17-0085.1.

Mlawer, E. J., S. J. Taubman, P. D. Brown, M. J. Iacono, and S. A. Clough, 1997: Radiative transfer for inhomogeneous atmospheres: RRTM, a validated correlated-k model for the longwave. J. Geophys. Res., 102, 16 663-16682, https://doi.org/ 10.1029/97JD00237.

Parker, M. D., 2008: Response of simulated squall lines to low-level cooling. J. Atmos. Sci., 65, 1323-1341, https://doi.org/10.1175/ 2007JAS2507.1.

Reif, D. W., and H. B. Bluestein, 2017: A 20-year climatology of nocturnal convection initiation over the central and southern Great Plains during the warm season. Mon. Wea. Rev., 145, 1615-1639, https://doi.org/10.1175/MWR-D-16-0340.1.

Roberts, R. D., and S. Rutledge, 2003: Nowcasting storm initiation and growth using GOES- 8 and WSR-88D data. Wea. Forecasting, 18, 562-584, https://doi.org/10.1175/1520-0434(2003) $018<0562$ :NSIAGU $>2.0 . \mathrm{CO} ; 2$.

Shapiro, A., E. Fedorovich, and J. G. Gebauer, 2018: Mesoscale ascent in nocturnal low-level jets. J. Atmos. Sci., 75, 14031427, https://doi.org/10.1175/JAS-D-17-0279.1.

Skamarock, W., and Coauthors, 2008: A description of the Advanced Research WRF, version 3. NCAR Tech. Note NCAR/ TN-475+STR, Mesoscale and Microscale Meteorology Division, National Center for Atmospheric Research, Boulder, CO, 125 pp., https://doi.org/10.5065/D68S4MVH.

Stelten, S., and W. A. Gallus, 2017: Pristine nocturnal convective initiation: A climatology and preliminary examination of predictability. Wea. Forecasting, 32, 1613-1635, https:// doi.org/10.1175/WAF-D-16-0222.1.

Su, T., and G. Zhai, 2017: The role of convectively generated gravity waves on convective initiation: A case study. Mon. Wea. Rev., 145, 335-359, https://doi.org/10.1175/MWR-D16-0196.1.

Tao, S. Y., and L. X. Chen, 1987: A review of recent research on the East Asian summer monsoon in China. Monsoon Meteorology, C. P. Chang and T. N. Krishnamurti, Eds., Oxford University Press, 60-92.

Trier, S. B., C. A. Davis, D. A. Ahijevych, M. L. Weisman, and G. H. Bryan, 2006: Mechanisms supporting long-lived episodes of propagating nocturnal convection within a 7-day WRF Model simulation. J. Atmos. Sci., 63, 2437-2461, https:// doi.org/10.1175/JAS3768.1.
,-- , and K. W. Manning, 2014: Use of the parcel buoyancy minimum (Bmin) to diagnose simulated thermodynamic destabilization. Part II: Composite analysis of mature MCS environments. Mon. Wea. Rev., 142, 967-990, https:// doi.org/10.1175/MWR-D-13-00273.1.

—, J. W. Wilson, D. A. Ahijevych, and R. A. Sobash, 2017: Mesoscale vertical motions near nocturnal convection initiation in PECAN. Mon. Wea. Rev., 145, 2919-2941, https:// doi.org/10.1175/MWR-D-17-0005.1.

Wallace, J. M., 1975: Diurnal variations in precipitation and thunderstorm frequency over the conterminous United States. Mon. Wea. Rev., 103, 406-419, https://doi.org/10.1175/15200493(1975)103<0406:DVIPAT > 2.0.CO;2.

Weckwerth, T. M., 2000: The effect of small-scale moisture variability on thunderstorm initiation. Mon. Wea. Rev., 128, 4017-4030, https://doi.org/10.1175/1520-0493(2000)129<4017: TEOSSM $>2.0 . \mathrm{CO} ; 2$

— , and D. B. Parsons, 2006: A review of convection initiation and motivation for IHOP_2002. Mon. Wea. Rev., 134, 5-22, https://doi.org/10.1175/MWR3067.1.

- and Coauthors, 2004: An overview of the International $\mathrm{H}_{2} \mathrm{O}$ Project (IHOP_2002) and some preliminary highlights. Bull. Amer. Meteor. Soc., 85, 253-277, https://doi.org/10.1175/ BAMS-85-2-253.

Whiteman, C. D., X. Bian, and S. Zhong, 1997: Low-level jet climatology from enhanced rawinsonde observations at a site in the southern Great Plains. J. Appl. Meteor., 36, 1363-1376, https:// doi.org/10.1175/1520-0450(1997)036<1363:LLJCFE >2.0.CO;2.

Wilson, J. W., and R. D. Roberts, 2006: Summary of convective storm initiation and evolution during IHOP: Observational and modeling perspective. Mon. Wea. Rev., 134, 23-47, https:// doi.org/10.1175/MWR3069.1.

_ S. B. Trier, D. W. Reif, R. D. Roberts, and T. M. Weckwerth, 2018: Nocturnal elevated convection initiation of the PECAN 4 July hailstorm. Mon. Wea. Rev., 146, 243-262, https://doi.org/ 10.1175/MWR-D-17-0176.1.

Yu, R., T. Zhou, A. Xiong, Y. Zhu, and J. Li, 2007: Diurnal variations of summer precipitation over contiguous China. Geophys. Res. Lett., 34, L01704, https://doi.org/10.1029/ 2006GL028129.

Zheng, L.-L., J.-H. Sun, X.-L. Zhang, and C.-H. Liu, 2013: Organizational modes of mesoscale convective systems over central east China. Wea. Forecasting, 28, 1081-1098, https://doi.org/ 10.1175/WAF-D-12-00088.1.

Zhu, X., and J. Zhu, 2004: New generation weather radar network in China (in Chinese with English abstract). Mater. Sci. Technol., 32, 255-258. 